\title{
Sub-arc mantle enrichment in the Sunda rear-arc inferred from HFSE systematics in high-K lavas from Java
}

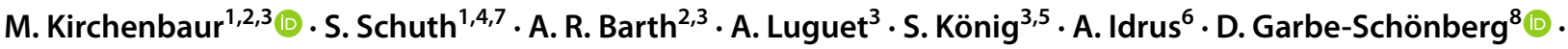 \\ C. Münker ${ }^{2,3}$ (])
}

Received: 20 April 2021 / Accepted: 30 November 2021 / Published online: 21 December 2021

(c) The Author(s) 2021

\begin{abstract}
Many terrestrial silicate reservoirs display a characteristic depletion in $\mathrm{Nb}$, which has been explained in some studies by the presence of reservoirs on Earth with superchondritic $\mathrm{Nb} / \mathrm{Ta}$. As one classical example, K-rich lavas from the Sunda rear-arc, Indonesia, have been invoked to tap such a high- $\mathrm{Nb} / \mathrm{Ta}$ reservoir. To elucidate the petrogenetic processes active beneath the Java rear-arc and the causes for the superchondritic $\mathrm{Nb} / \mathrm{Ta}$ in some of these lavas, we studied samples from the somewhat enigmatic Javanese rear-arc volcano Muria, which allow conclusions regarding the across-arc variations in volcanic output, source mineralogy and subduction components. We additionally report some data for an along-arc sequence of lavas from the Indonesian part of the Sunda arc, extending from Krakatoa in the west to the islands of Bali and Lombok in the east. We present major and trace element concentrations, $\mathrm{Sr}-\mathrm{Nd}-\mathrm{Hf}-\mathrm{Pb}$ isotope compositions, and high-field-strength element (HFSE: $\mathrm{Nb}, \mathrm{Ta}, \mathrm{Zr}, \mathrm{Hf}, \mathrm{W}$ ) concentrations obtained via isotope dilution and MC-ICP-MS analyses. The geochemical data are complemented by melting models covering different source compositions with slab melts formed at variable P-T conditions. The radiogenic isotope compositions of the frontal arc lavas in combination with their trace element systematics confirm previously established regional variations of subduction components along the arc. Melting models show a clear contribution of a sediment-derived component to the HFSE budget of the frontal arc lavas, particularly affecting $\mathrm{Zr}-\mathrm{Hf}$ and $\mathrm{W}$. In contrast, the K-rich rear-arc lavas tap more hybrid and enriched mantle sources. The HFSE budget of the rear-arc lavas is in particular characterized by superchondritic $\mathrm{Nb} / \mathrm{Ta}$ (up to 25 ) that are attributed to deep melting involving overprint by slab melts formed from an enriched garnet-rutile-bearing eclogitic residue. Sub-arc slab melting was potentially triggered along a slab tear beneath the Sunda arc, which is the result of the forced subduction of an oceanic basement relief $\sim 8$ Myr ago as confirmed by geophysical studies. The purported age of the slab tear coincides with a paucity in arc volcanism, widespread thrusting of the Javanese basement crust as well as the short-lived nature of the K-rich rear-arc volcanism at that time.
\end{abstract}

Keywords Rear-arc volcanism $\cdot$ Superchondritic $\mathrm{Nb} / \mathrm{Ta} \cdot \mathrm{Muria} \cdot \mathrm{Sunda}$ arc

Communicated by Timm John.

M. Kirchenbaur

m.kirchenbaur@mineralogie.uni-hannover.de

1 Institut für Mineralogie, Leibniz Universität Hannover, 30167 Hannover, Germany

2 Institut für Geologie und Mineralogie, Universität zu Köln, 50674 Köln, Germany

3 Institut für Geowissenschaften, Rheinische Friedrich-Wilhelms-Universität Bonn, 53113 Bonn, Germany

4 Geographisches Institut, Universität zu Köln, 50674 Köln, Germany
5 Instituto Andaluz de Ciencias de la Tierra (IACT), Consejo Superior de Investigaciones Científicas and Universidad de Granada, 18100 Granada, Spain

6 Department of Geological Engineering, Universitas Gadjah Mada, Yogyakarta 55281, Indonesia

7 Institut für Mineralogie, Geologie und Geophysik, Ruhr-Universität Bochum, 44801 Bochum, Germany

8 Institut für Geowissenschaften, Christian-Albrechts-Universit ät zu Kiel, 24118 Kiel, Germany 


\section{Introduction}

The marked depletion of $\mathrm{Nb}$ in most reservoirs of the silicate Earth relative to Ta if compared to chondrites is well known, and its origin is matter of scientific debate (e.g., Rudnick et al. 2000; Wade and Wood 2001; Cartier et al. 2014; Münker et al. 2003, 2017). Earlier models explaining this selective $\mathrm{Nb}$ depletion involve a more siderophile behaviour of $\mathrm{Nb}$ during core formation (Wade and Wood 2001; Cartier et al. 2014), or the presence of a hidden refractory eclogite reservoir with high Nb/Ta (e.g., Rudnick et al. 2000). Recently, Münker et al. (2017) proposed that the $\mathrm{Nb}$ deficit of the silicate Earth might already constitute an inherited feature of Earth's building blocks. Nevertheless, high precision $\mathrm{Nb} / \mathrm{Ta}$ measurements in mafic intraplate lavas derived from the lithospheric mantle (Pfänder et al. 2012) suggest that the latter may also constitute a putative high- $\mathrm{Nb} / \mathrm{Ta}$ reservoir.

To investigate the processes triggering selective $\mathrm{Nb}$ enrichment in the lithospheric mantle, an in-depth understanding of $\mathrm{Nb}-\mathrm{Ta}$ geochemistry during subduction processes is essential. In general, island-arc lavas exhibit a characteristic depletion of the high-field strength elements (HFSE) such as $\mathrm{Nb}-\mathrm{Ta}$ and occasionally $\mathrm{Zr}-\mathrm{Hf}$ relative to the more fluid-mobile large-ion lithophile elements (LILE) or light rare earth elements (LREE; e.g., Pearce and Peate 1995) and sometimes also compared to MORB. The HFSE depletion is interpreted as either reflecting the presence of residual Ti-rich phases such as rutile in the subducting slab or, alternatively, the somewhat lower fluid mobility of $\mathrm{Nb}$ and $\mathrm{Ta}$ across the slab-mantle wedge interface (e.g., Brenan et al. 1994; Tanis et al. 2015). Notably, lavas from rear-arc (e.g., Whitford 1975) or post-collisional environments (Kirchenbaur and Münker 2015) frequently show an increasing enrichment of $\mathrm{K}$ that is often complemented by enrichments of $\mathrm{Nb}-\mathrm{Ta}$ and other incompatible elements (LREE, LILE). This enrichment is readily interpreted as reflecting more fertile mantle sources that owe their characteristic HFSE budget to the breakdown of accessory HFSE-bearing minerals in subducted sediments or the subducted mafic portion of the slab with progressive subduction, thus facilitating their transport across the slab-mantle wedge interface by melts or fluids (Tatsumi 1989; Elliott et al. 1997; Hermann and Rubatto 2009).

One of the key localities to evaluate such models is the island arc-/rear-arc system of the Sunda arc in Indonesia (Edwards et al. 1994; van Bergen et al. 1993; Handley et al. 2007, 2011; Turner et al. 2014; Varne 1985; Leterrier et al. 1990; Stolz et al. 1996). The Sunda arc is well examined and comprises a unique spectrum of medium-K to high-K front arc and rear-arc volcanism, making it a highly suited location to study trace element behaviour along and across-arc (e.g., Handley et al. 2014). Additionally, the composition of local subducting sediments is well known (e.g., Vroon et al. 1995; Nebel et al. 2010; Turner et al. 2014), thus facilitating the identification of endmember compositions. Previous studies identified alongarc variations that are the result of changing subduction components (e.g., Handley et al. 2014), which allow for an assessment of the HFSE behaviour along the relevant sectors of the Sunda arc. Placed into this context, the hitherto sparsely investigated rear-arc volcanoes Muria and Ringgit may give important insights into geochemical variations across the Sunda arc that in turn provide information about mantle source variations and processes like fluid release or partial slab melting with progressive subduction.

In the present study, particular attention is given to the behaviour of the extended HFSE group $(\mathrm{Nb}-\mathrm{Ta}-\mathrm{Zr}-\mathrm{Hf}-\mathrm{W}-\mathrm{Mo})$, for which we present a dataset obtained via ID-MC-ICP-MS on powders exclusively prepared in an agate mill, thus excluding the possibility of HFSE contamination by tungsten carbide materials. Our new HFSE data are evaluated together with a dataset covering $\mathrm{Sr}-\mathrm{Nd}-\mathrm{Hf}-\mathrm{Pb}$ isotope compositions and trace elements in representative lavas of the major Sunda arc volcanoes (Krakatoa, Galunggung, Merapi to Bali and Lombok), which serve as our reference basis to evaluate across-arc HFSE variations to the K-rich rear-arc volcanoes Muria and Ringgit.

\section{Geological background}

\section{Geological setting and sample localities}

The active Sunda-Banda arc extends over a length of $6000 \mathrm{~km}$ (Turner and Foden 2001) from the Andaman Islands to the Banda Sea (see Fig. 1) and formed by subduction of the Indo-Australian plate beneath the Eurasian plate. Active subduction along the Sunda arc commenced in the late Eocene or early Oligocene (Hamilton 1979), triggered by the India-Asia collision at about $45 \mathrm{Ma}$ in the Eocene (Hall 2002). The counterclockwise rotation of Borneo at 25-10 Ma caused a strong reduction of the volcanic activity on Java, Bali and Lombok (Hall 2002). Subsequently, subduction resumed again in the mid-Miocene (Hall 2002), starting the main tectonic and volcanic phase (Katili 1975). More recent volcanism along the whole Sunda arc started in the Pliocene and has ranged from intermediate lava compositions in Java to more mafic compositions towards the east (Hamilton 1979).

The Sunda arc was originally divided into three volcanic chains parallel to the active Java Trench (van Bemmelen 1970). The Benioff zone beneath the first volcanic chain, where for example Krakatoa is located, is about 
Fig. 1 Overview of the SundaBanda arc with the study area and sampling localities extending from Krakatoa to Lombok. Map modified from: www. mapsofworld.com. Stippled lines show the depth of the Benioff zone beneath Java (after Hamilton 1979). Central Java fault (CJF) after HoffmannRothe et al. (2001) and Chotin et al. (1984), P-M-L (ProgoMuriah Lineament) after Handley et al. (2014)

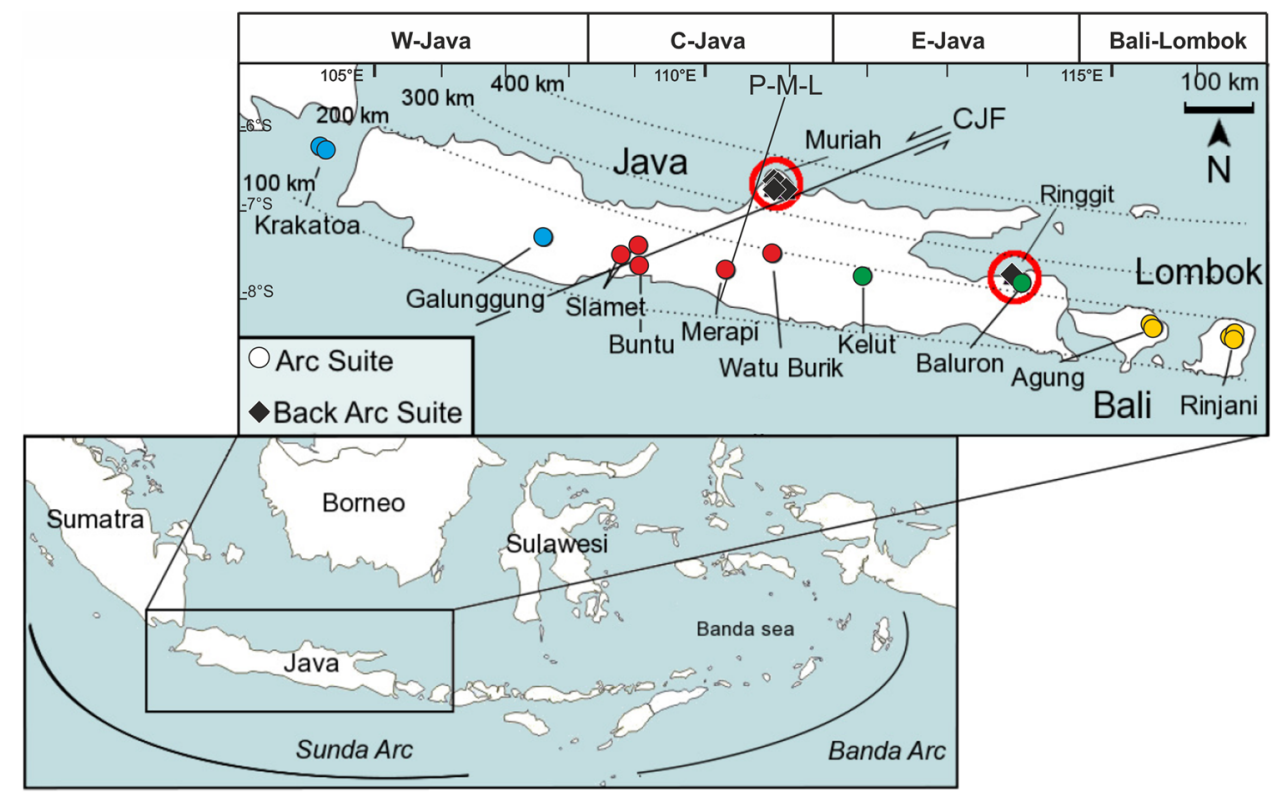

$110 \mathrm{~km}$ deep. Beneath the second volcanic chain the Benioff zone is about $180 \mathrm{~km}$ deep. Most of the sampled volcanoes are part of this second chain (e.g., Merapi). The Benioff zone beneath the third chain, including the rear-arc volcano Muria, is about $360 \mathrm{~km}$ deep (see Fig. 1), a depth from which partial melt extraction from either the mantle wedge or the subducted plate is highly unlikely at present P-T conditions (e.g., Nicholas 1986). As such, volcanic activity in the rear-arc region of the Sunda arc is somewhat enigmatic. There are hints for a special plate configuration beneath Central Java, which may account for the volcanism in the rear-arc region, such as a boundary between two different subducted segments (Hamilton 1979; Varekamp et al. 1989), a thinned plate (Widiyantoro and van der Hilst 1996), or an interplay of both. Edwards et al. (1994) noted that Muria is positioned at an intersection between the Sundaland craton to the East and the extensional Bawean trough, possibly represented by the ProgoMuria lineament (Smyth et al. 2007) or the Central Java Fault (see Fig. 1; Chotin et al. 1984; Hoffmann-Rothe et al. 2001). Based on $\mathrm{Sr}$ isotope data and volcano morphology and activity, Handley (2006) proposed a major crustal boundary between Central and Eastern Java and placed the location of Muria at the intersection of the Progo-Muria lineament and the Central Java Fault (see Fig. 1; see also Handley et al. 2014). However, Widiyantoro and van der Hilst (1996) found a seismic gap beneath Java, which may indicate a thinned or torn subducted plate, which was later on confirmed by further geophysical studies to represent a slab tear (Koulakov et al. 2007; Cottam et al. 2010; Widiyantoro et al. 2011; Hall and Spakman 2015).

\section{Sunda frontal arc}

Along-arc, the Sunda arc is divided from West to East in four sections: (1) West Java including Krakatoa, (2) Central Java, (3) East Java, and (4) Bali and Lombok. The samples analysed in this study cover all four sections. The border between Central and East Java is a major structural boundary, which is called the Progo-Muria lineament (Smyth et al. 2007) or alternatively the Central Java fault (Chotin et al. 1984; Hoffmann-Rothe et al. 2001), and lies close to Muria volcano at about $111^{\circ} \mathrm{E}$. Another major structure that might have considerable implications on the subduction zone geometry and source input is the subduction of an oceanic basement relief, the so-called Roo Rise, extending from Central to East Java between $110^{\circ} \mathrm{E}$ and $116^{\circ} \mathrm{E}$ (Kopp et al. 2006; Handley et al. 2014). It comprises thickened oceanic crust populated with seamounts reaching $2500 \mathrm{~m}$ in height relative to the surrounding ocean floor. The onset of the subduction of the Roo Rise is presently unknown; however, it causes large-scale uplift and erosion of the fore-arc and steepening of the lower slope angle in the Central Java sector (Kopp et al. 2006; Handley et al. 2014).

The Sunda island arc lavas comprise a large spectrum of compositions, from basaltic to andesitic and more evolved ones although intermediate compositions dominate the erupted volume (Katili 1975). Thickness and composition of the subducted sediment layer varies along the arc (Vroon et al. 1995; Nebel et al. 2010), with ca. $300 \mathrm{~m}$ of siliceous ooze, terrigeneous turbidites and clay-rich material at the Central Sunda Trench and ca. $500 \mathrm{~m}$ of sediments with higher carbonate contents towards the East Sunda Trench (Plank and Langmuir 1998). The variable types of sediment input are associated with significant differences 
in the geochemistry of, e.g., West and East Java volcanic lavas (Handley et al. 2014), which are marked by differences in $\mathrm{Pb}-\mathrm{Sr}-\mathrm{O}$ isotope compositions as well as trace element ratios of the respective lava suites. In their detailed and extensive study, Handley et al. (2014) addressed the long-standing debate on the effect of crustal assimilation and different assimilants on Javanese lavas. Based on $\mathrm{Pb}-\mathrm{O}$ isotopes and trace element systematics, Handley et al. (2014) identified different crustal materials that were incorporated to a small degree in the arc lavas during differentiation in the arc crust: (a) a predominantly ultra-mafic/mafic (ophiolitic) member in West Java, identified by, e.g. negative covariation of ${ }^{207} \mathrm{~Pb} /{ }^{204} \mathrm{~Pb}$ with $\mathrm{SiO}_{2}$ together with $\mathrm{O}$ isotope compositions and mineral-whole rock isotope modelling (Handley et al. 2014) and (b) an upper crustal carbonate material in Central Java, which was also previously identified by Chadwick et al. (2007) for Merapi lavas. In contrast, East Javanese lavas provide little to no evidence for crustal assimilation. Geochemical variability beyond the limited influence of crustal assimilation, mainly established by $\mathrm{Pb}$ isotopes as the most sensitive proxy, was primarily attributed to a variation in source components, i.e., mantle wedge composition and/or subducted component. As such, a higher fluid component and greater incorporation of detrital-poor (clay-rich) pelagic sediments was found in East Java relative to West Java lavas (Handley et al. 2014). Because it may enhance fluid-flux and the scavenging of fluid-mobile elements in the Eastern Java sector, the collision of the Roo Rise may account for the West-East transition of different subduction components.

\section{Sunda rear-arc}

In this study, two rear-arc volcanoes were specifically sampled, namely Muria (in the literature alternatively spelled Muriah or Mt. Mouriah) and Ringgit. Muria volcano is located in the rear-arc of central Java on crustal basement considered to be transitional between oceanic and continental compositions (Ben Avraham and Emery 1973). The crust reaches an approximate thickness of $\sim 20 \mathrm{~km}$, and is covered by Neogene oceanic sediments consisting of shales, sandstones, and limestones (Edwards et al. 1994). Muria was active during the Pleistocene and is now extinct (Iddings and Morley 1915; Nicholls and Whitford 1983; Koulakov et al. 2007). Two types of basaltic series were erupted at Muria: an older K-series (1.11-0.64 Ma; Edwards et al. 1994) and a younger leucite-bearing high-K series $(0.78-0.41 \mathrm{Ma}$; Edwards et al. 1994). The samples from Muria investigated here are exclusively from the younger high-K series. The extinct Ringgit volcano is part of the Ringgit-Beser complex (see Fig. 1). Van Bemmelen (1970) suggested a main phase of rear-arc volcanic activity between late Pliocene to late Pleistocene. Edwards et al. (1994) divided the volcanic rear-arc rocks into calc-alkaline, high-K calc-alkaline and high-K alkaline series (Peccerillo and Taylor 1976; Wheller et al. 1987).

\section{Sample selection/petrography}

This study includes 22 samples from 12 different volcanoes covering an area ranging from Krakatoa to Lombok Island (Fig. 1). Sampled volcanoes from west to east include: (1) Krakatoa, (2) Galunggung (West Java), (3) Slamet, Buntu, and Merapi. The volcanoes Watu and Burik, are close to the border between Central and East Java, but are listed here together with Central Java volcanoes, (4) Kelud and Baluran (East Java) and (5) Agung and Rinjani are located on Bali and Lombok, respectively. Although only one or two samples were sampled for each volcano, compositional characteristics are well representative of the volcanic suites as illustrated, e.g. for $\mathrm{Sr}-\mathrm{Pb}$ isotopes as well as $\mathrm{MgO}$ contents, while our $\mathrm{Hf}$ data seem to be at the most radiogenic end of the data sets published so far (see, e.g. Fig. 4c, d and Appendix as compiled from the Georoc database; for details of sample screening, see the Appendix).

Most samples are of mafic-intermediate composition, devoid of alteration and contain olivine, pyroxene and plagioclase phenocrysts to varying amounts. Exceptions are the $\mathrm{Ne}$ - and Lc-normative samples from the rear-arc volcano Muria that contain abundant analcime, a pseudomorph after leucite (Putnis and Putnis 2007), as a major mineral phase (up to $37 \mathrm{wt} . \%$ ). Only geochemically diverse samples with $\mathrm{MgO}>3.5$ wt. \% were chosen for further trace element and isotope analyses.

\section{Results}

The major and trace element results as well as $\mathrm{Sr}-\mathrm{Nd}-\mathrm{Hf}-\mathrm{Pb}$ isotope compositions are reported in Table 1, and HFSE isotope dilution (ID) data are shown in Table 2. Analytical details can be found in Appendix B and C.

\section{Major elements}

The studied samples can be divided into two groups based on their localities and K concentration: (1) a frontal arc suite with low to moderate $\mathrm{K}$ content (calc-alkaline- to high-K calc-alkaline series after Peccerillo and Taylor 1976; see Fig. 2a), and (2) a rear-arc suite with high-K contents (volcanoes Muria and Ringgit; shoshonite series after Peccerillo and Taylor 1976; Fig. 2a). Whereas the frontal arc rocks are quartz-normative basalts to basaltic andesites, the reararc rocks are olivine- and nepheline-normative and have $\mathrm{K}_{2} \mathrm{O}$ concentrations ranging from 3.0 to $5.5 \mathrm{wt}$. \%. As their $\mathrm{K}_{2} \mathrm{O} / \mathrm{Na}_{2} \mathrm{O}$ is clearly below 2 , they are potassic and not 
ultrapotassic (Foley et al. 1987). There is no significant difference between the two suites in their $\mathrm{SiO}_{2}$ contents (see Fig. 2a, b) or Mg\# as the arc suite ranges in $\mathrm{Mg \#}$ from 41 to 68, whereas the rear-arc suite ranges in Mg\# from 30 to 76. The sample from Ringgit (I25Pe1) is distinctively different with its low $\mathrm{SiO}_{2}$ at high $\mathrm{MgO}$ (15.1 wt.\%) and alkali content $\left(\mathrm{Na}_{2} \mathrm{O}+\mathrm{K}_{2} \mathrm{O}=6.60\right)$. The sample is additionally characterized by high $\mathrm{Ni}$ and $\mathrm{Cr}$ contents (387 and 912 ppm).

\section{Trace elements}

The trace element patterns (Fig. 3 inset) show an overall LREE enrichment, however, both sample suites can be clearly distinguished based on their LREE patterns. The frontal arc suite displays $\mathrm{La}_{\mathrm{N}} / \mathrm{Yb}_{\mathrm{N}}$ of $1.8-5.0$ and the rear-arc suite of 27.4-48.3. No distinct Eu or Ce anomalies are observed in either suite. The different degrees of enrichment are also reflected in the multi-trace element patterns (Fig. 3). All samples are strongly LILE (large ion lithophile elements) enriched. The most pronounced differences, however, include striking depletions of the HFSE $\mathrm{Nb}-\mathrm{Ta}, \mathrm{Zr}-\mathrm{Hf}$, and $\mathrm{Ti}$ as well as for $\mathrm{Pb}$ in some samples in the rear-arc suite in an otherwise steep and smooth pattern. The frontal arc suite shows various depletions of the HFSE, and a pronounced positive $\mathrm{Pb}$ anomaly.

\section{$\mathrm{Sr}-\mathrm{Nd}-\mathrm{Hf}-\mathrm{Pb}$ isotope compositions}

The isotope compositions of the erupted lavas show a correlation with the geographical location of the arc suite, i.e., the Central Sunda arc display more radiogenic ${ }^{87} \mathrm{Sr} /{ }^{86} \mathrm{Sr}$ $(0.7045-0.7059)$ and elevated ${ }^{207} \mathrm{~Pb} /{ }^{204} \mathrm{~Pb}(15.69-15.75)$ compared to the more eastern sectors (see Fig. $4 \mathrm{a}-\mathrm{c}$ ). The other frontal arc lavas (Krakatoa, East Java, Bali-Lombok) as well as the rear-arc suite overlap in their $\mathrm{Sr}-\mathrm{Pb}$ isotope compositions $\left({ }^{87} \mathrm{Sr} /{ }^{86} \mathrm{Sr}\right.$ from 0.7039 to 0.7046 , and ${ }^{207} \mathrm{~Pb} /{ }^{204} \mathrm{~Pb}$ from 15.59 to 15.66 ). As shown in Fig. $4 \mathrm{a}-\mathrm{c}$, the $\mathrm{Sr}$ and $\mathrm{Pb}$ isotope compositions of our samples are in good agreement with data compiled from the literature and the Georoc database.

In $\varepsilon \mathrm{Hf}-\varepsilon \mathrm{Nd}$ space, all samples are offset from the mantle array towards less radiogenic $\varepsilon \mathrm{Nd}$ (Fig. 4d). The frontal arc suite lavas are more radiogenic in $\mathrm{Hf}$ and $\mathrm{Nd}$ isotope compositions $(\varepsilon \mathrm{Hf}=12.2-15.3 ; \varepsilon \mathrm{Nd}=1.5-5.7)$ than the rear-arc suite $(\varepsilon \mathrm{Hf}=3.6-6.3 ; \varepsilon \mathrm{Nd}=-1.1$ to 2.4$)$. Isotope compositions of the rear-arc suite plot closer to those of typical local ocean floor sediments (Vroon et al. 1995; Nebel et al. 2010).

\section{HFSE}

High-precision ID measurements for $\mathrm{Nb}, \mathrm{Ta}, \mathrm{Zr}, \mathrm{Hf}$, and $\mathrm{W}$ for the rear-arc suite revealed high concentrations of all HFSE (Nb: $36.5-93.6 \mu \mathrm{g} / \mathrm{g}$, Ta: $2.07-3.78 \mu \mathrm{g} / \mathrm{g}$, $\mathrm{Zr}: 124-313 \mu \mathrm{g} / \mathrm{g}$, Hf: $3.14-6.42 \mu \mathrm{g} / \mathrm{g}$, and $\mathrm{W}$ : $1.05-2.19 \mu \mathrm{g} / \mathrm{g}$ ). Ratios of $\mathrm{Nb} / \mathrm{Ta}$ (between 17.7 and 24.7) in the rear-arc suite are partly superchondritic, but are somewhat lower than earlier reported values of up to 33.1 by Stolz et al. $(\mathrm{Nb} / \mathrm{Ta}=16.8-33.1 ; 1996)$, which were obtained via SSMS and INAA.

Relevant HFSE ratios of the frontal arc and rear-arc suites are illustrated in Fig. 5 compared to the MORB array shown in Münker et al. (2004; after Büchl et al. 2002), arc lavas from the Solomon Islands that reflect sub-arc mantle enrichment by slab-derived melts (Schuth et al. 2004, 2009; König et al. 2008; König and Schuth 2011), and local subducting sediments (Nebel et al. 2010). In Fig. 6, some diagnostic HFSE ratios are shown for the frontal arc lavas regarding their latitudinal position.

The HFSE concentrations of the frontal arc suite lavas are considerably lower than in the rear-arc suite (Fig. 3). $\mathrm{The} \mathrm{Zr} / \mathrm{Hf}$ of the frontal arc suite lavas range from 30.6 to 40.6 and those of the rear-arc suite from 37.7 to 48.8 . Compared to major terrestrial silicate reservoirs (Barth et al. 2000; Münker et al. 2003), the frontal arc suite overlaps the MORB field in $\mathrm{Nb} / \mathrm{Ta}-\mathrm{Zr} / \mathrm{Hf}$ space (Fig. 5a) and also shows a negative co-variation between $\mathrm{Zr} / \mathrm{Hf}$ and $\mathrm{Lu} /$ Hf (Fig. 5b). Conversely, the rear-arc lavas show a strong positive correlation between $\mathrm{Nb} / \mathrm{Ta}$ vs. $\mathrm{Zr} / \mathrm{Hf}$ but no correlation between $\mathrm{Lu} / \mathrm{Hf}$ and $\mathrm{Zr} / \mathrm{Hf}$.

Owing to the high mobility of $\mathrm{W}$ in subduction zone fluids (König et al. 2008), ratios like W/Th or Ta/W, especially in combination with other fluid proxies like $\mathrm{Sb} / \mathrm{Ce}$ or $\mathrm{Ce} / \mathrm{Pb}$, can give vital information about fluidmediated source overprint (see Fig. 7). The W/Th in the rear-arc lavas range from 0.021 to 0.149 (lower than or overlapping with MORB) and correlations with other fluid proxies (e.g. $\mathrm{Ba} / \mathrm{Th}$ ) are absent. In contrast to the rear-arc lavas, W/Th in the frontal arc lavas range from 0.0911 to 0.320 (overlapping with and also exceeding MORB values) with the highest W/Th and $\mathrm{Sb} / \mathrm{Ce}$ found in two samples from East Java as well as the sample from Galunggung (sample I3Ga1; West-Java; Fig. 7b). These W/Th are still considerably lower than those found in arcs with a high flux of fluids and/or sediments where W/ Th of up to 1 were found (e.g., as is the case for Cyprus; König et al. 2008). 


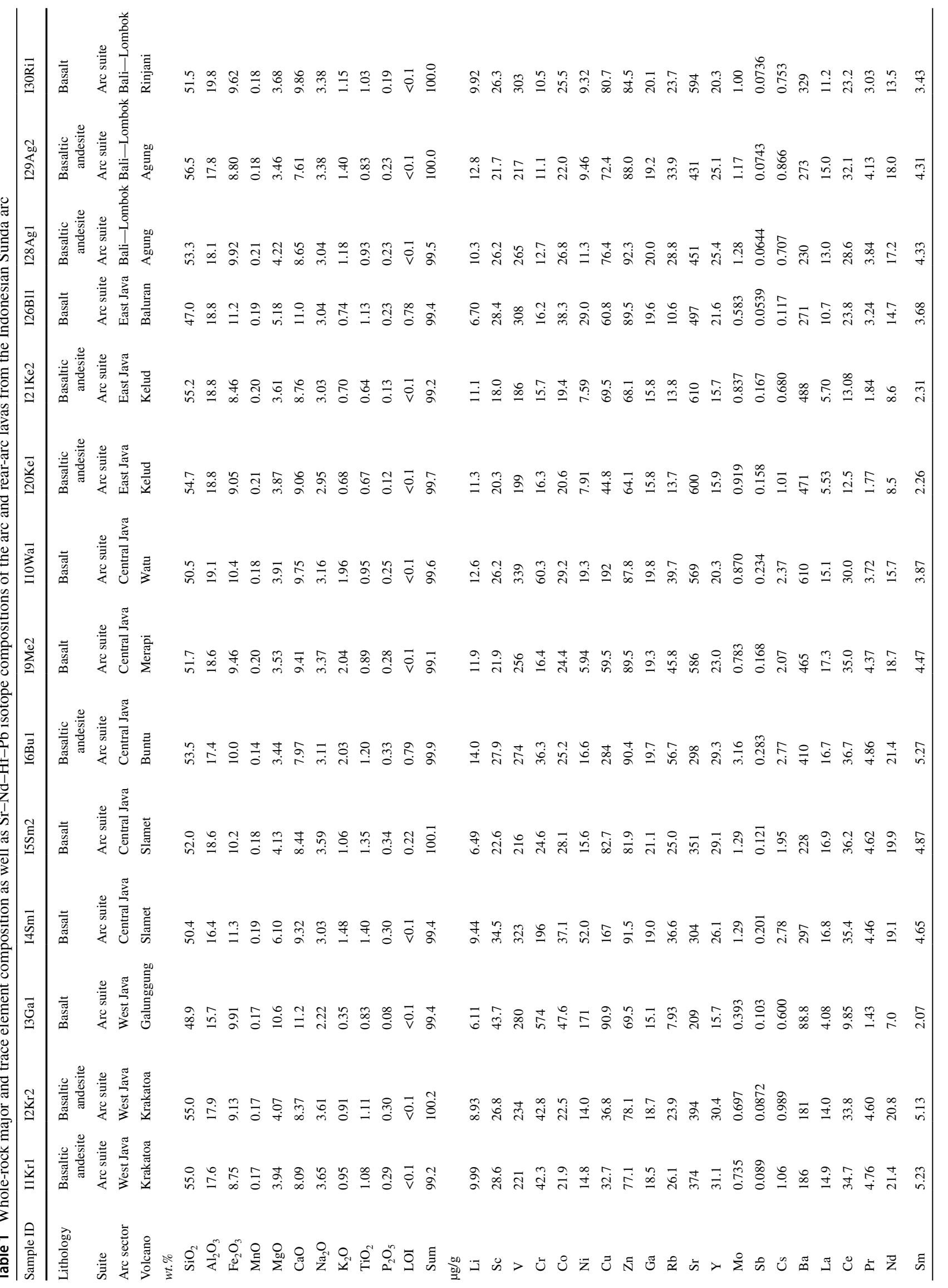




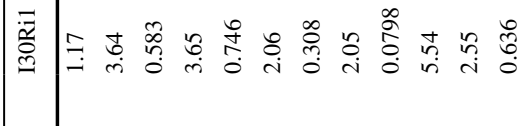

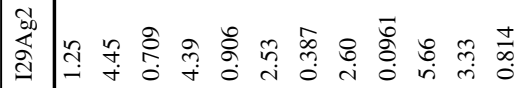

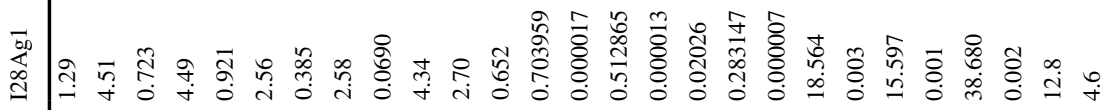

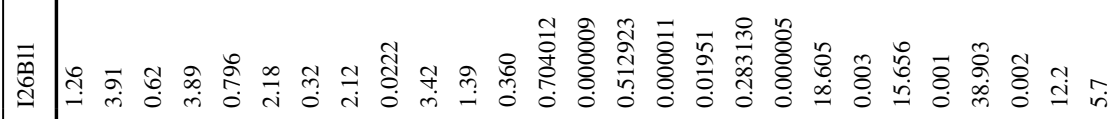

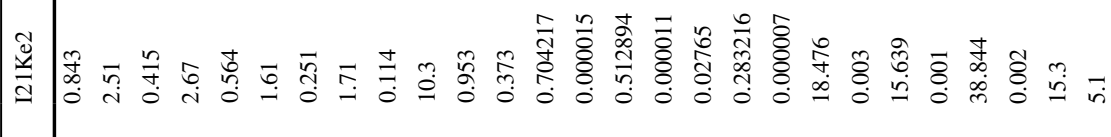

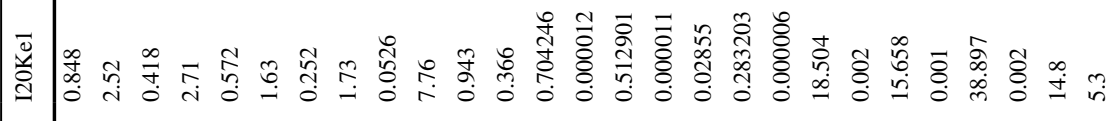

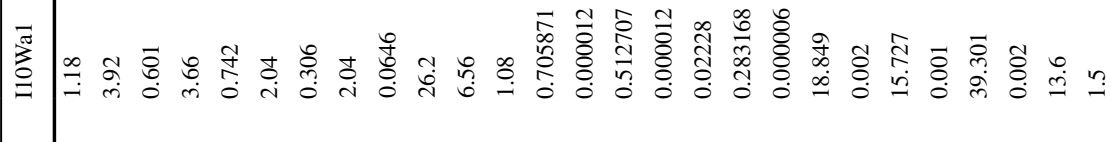

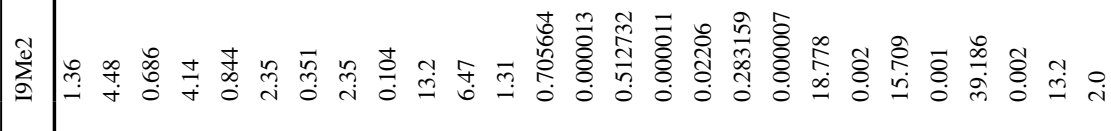

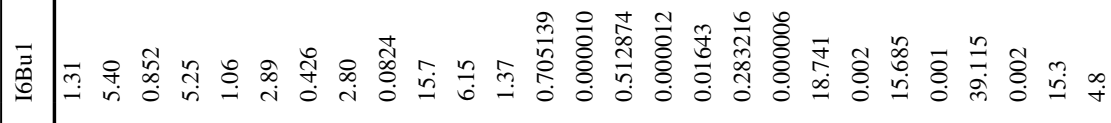

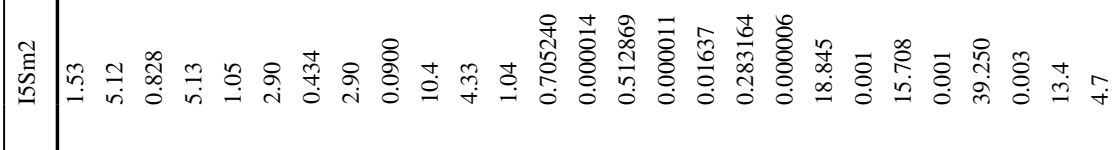

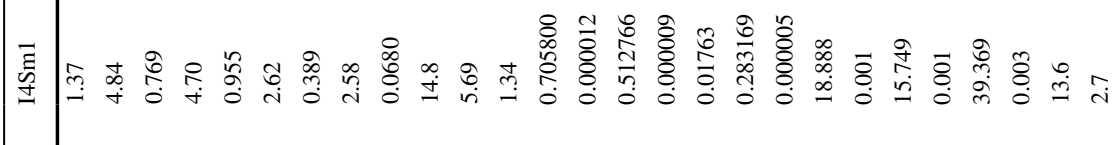

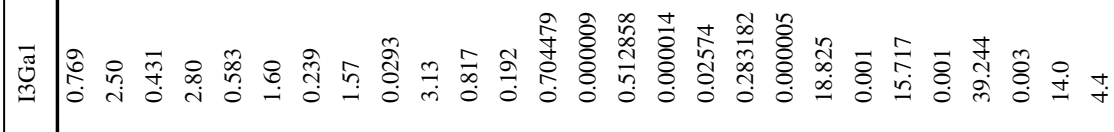

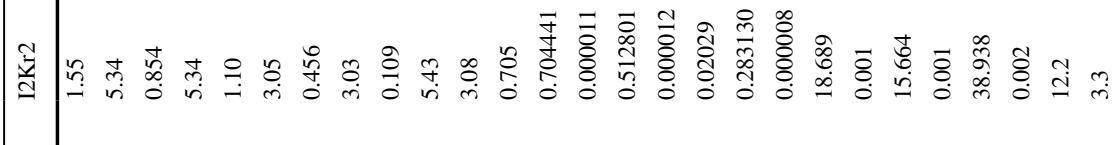

ت

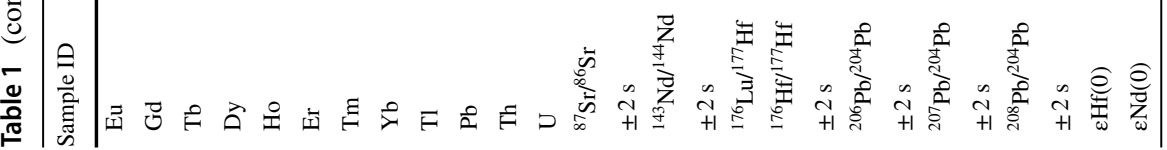




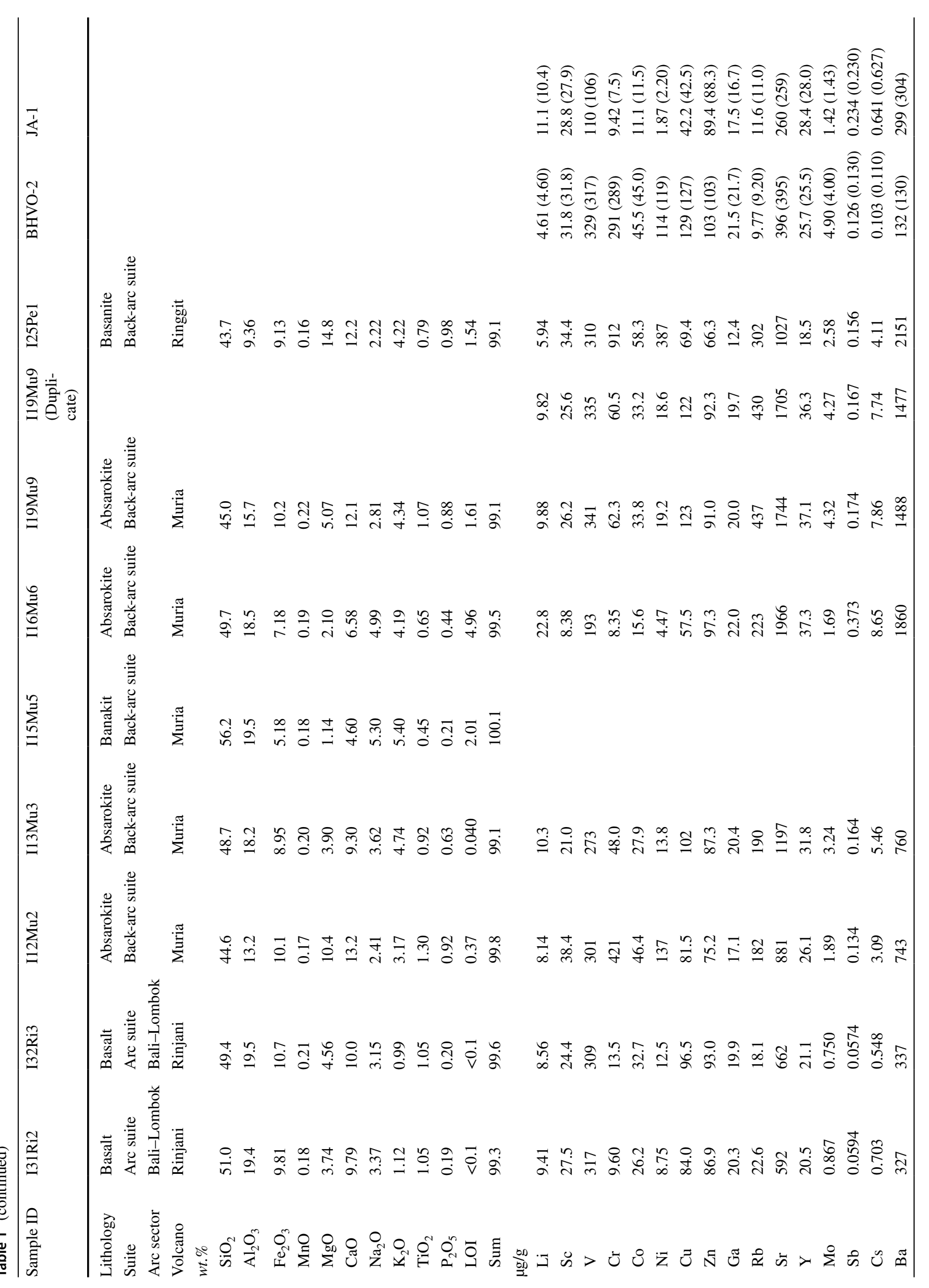




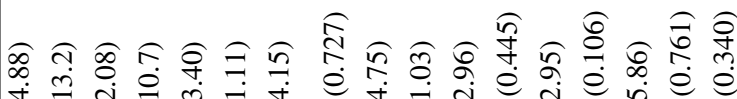

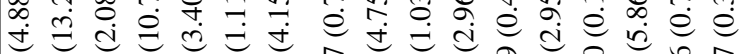

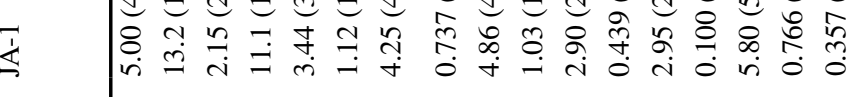

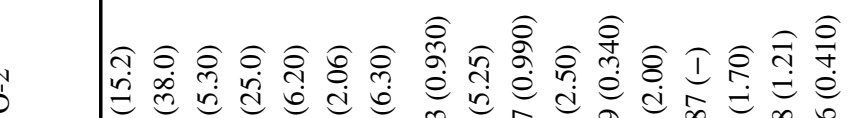

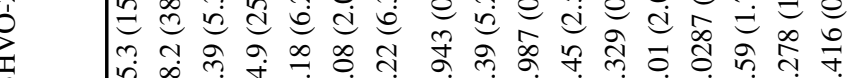

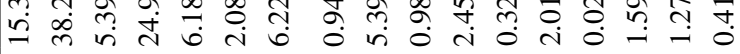

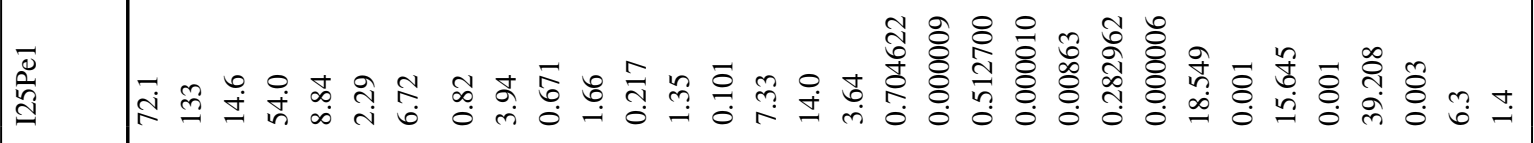

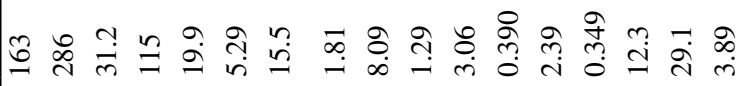

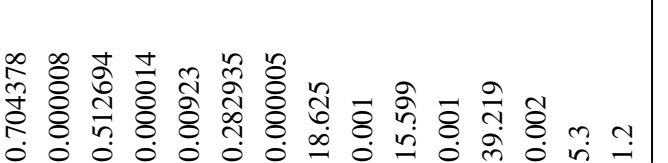

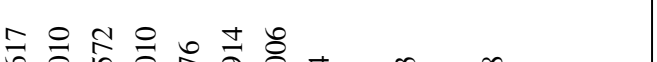

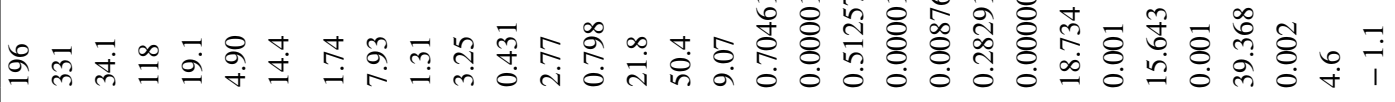

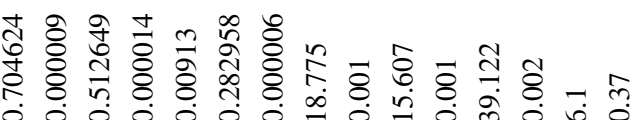

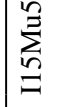

$\stackrel{\sum}{=}$

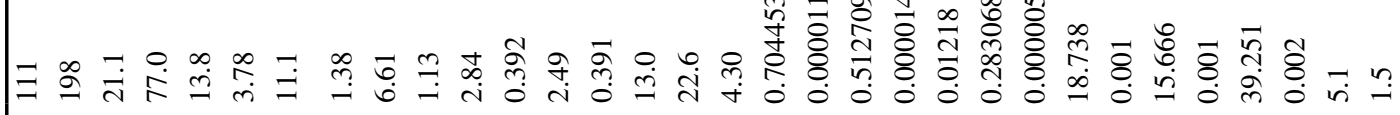

节

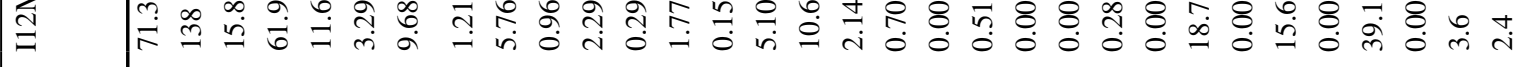

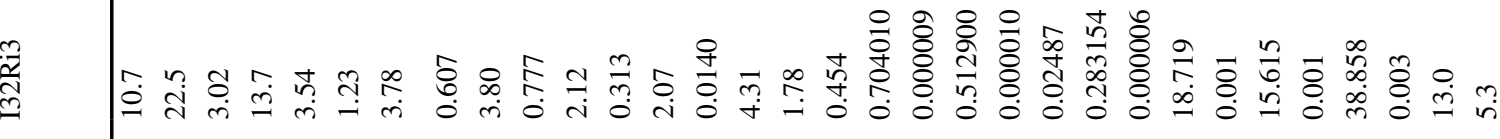

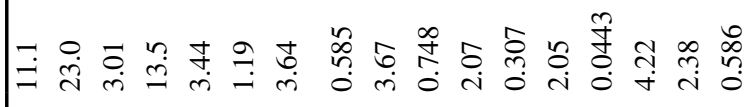




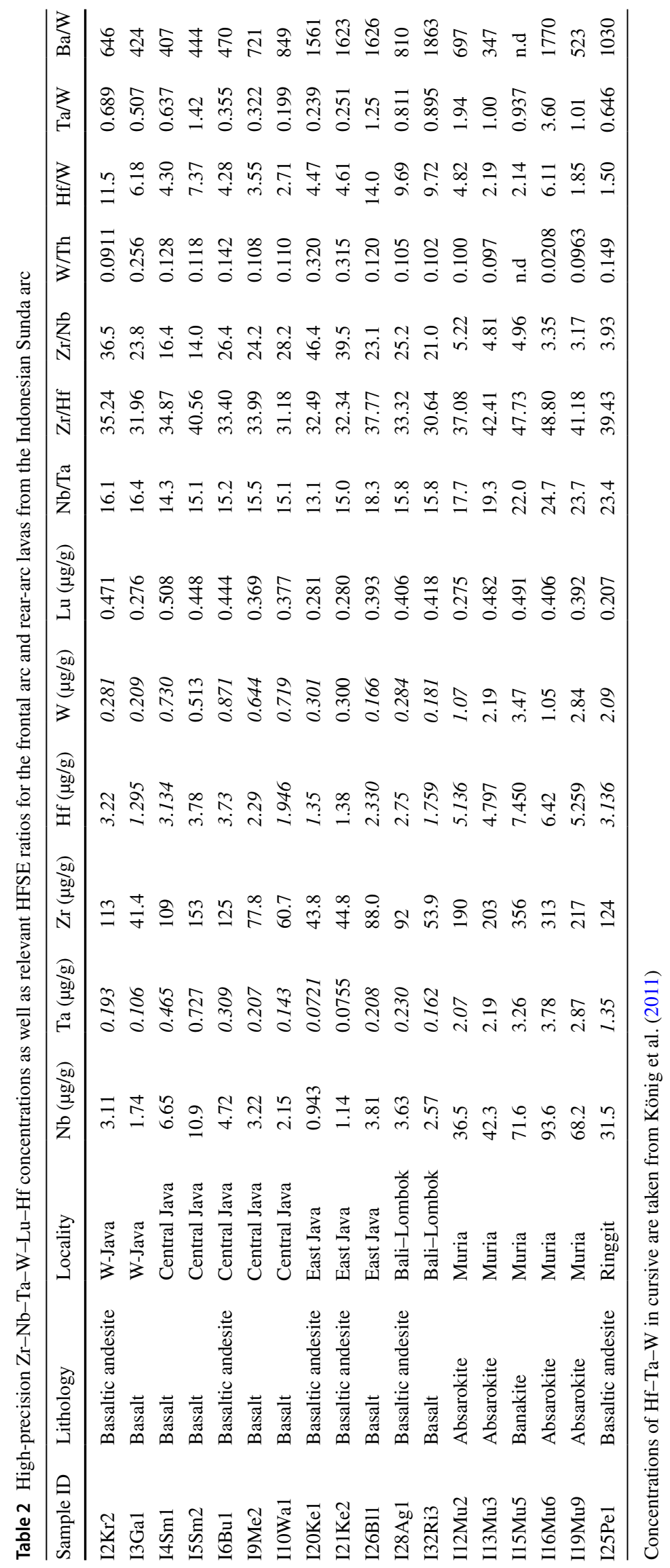




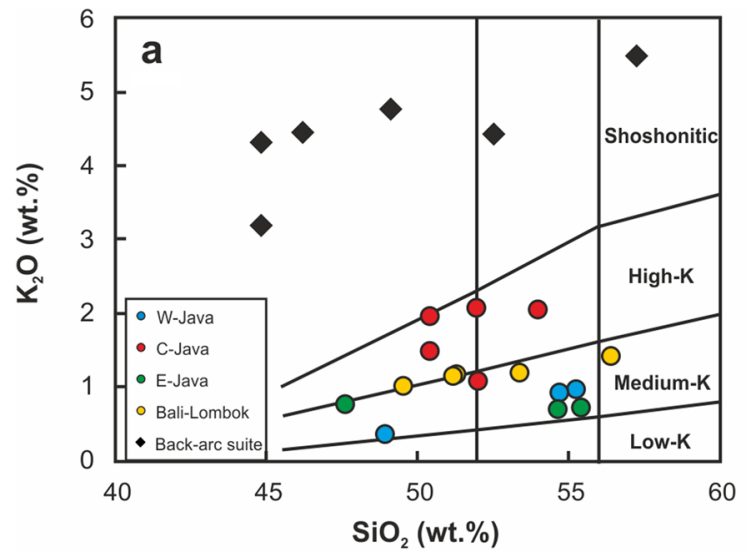

Fig. 2 a Major element classification of the arc and rear-arc samples after Peccerillo and Taylor (1976); b Influence of AFC processes on relevant HFSE ratios, exemplified here by $\mathrm{Nb} / \mathrm{Ta}$ versus $\mathrm{SiO}_{2}$ content.

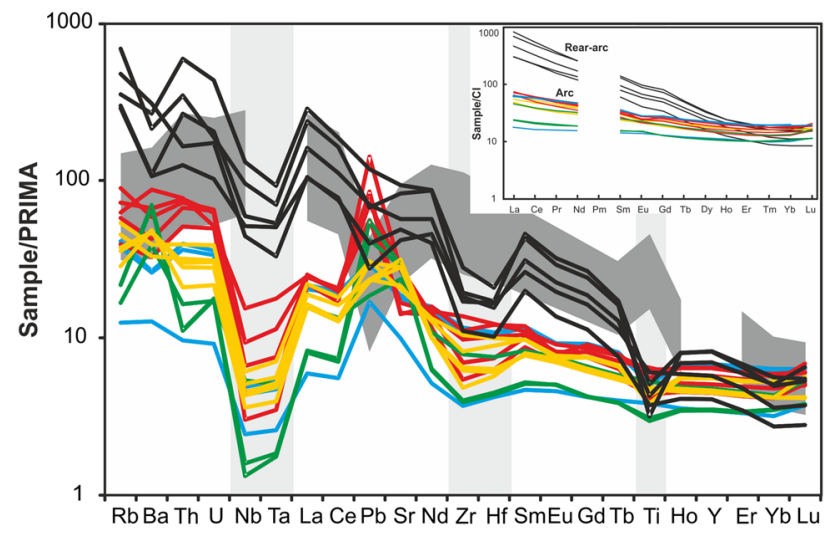

Fig. 3 Trace element systematic of the arc and rear-arc lavas plotted normalized on PRIMA values (Sun and McDonough 1989). Inlet shows REE normalized to CI chondrite (Sun and McDonough 1989). Colour-code as in Fig. 2. Range of OIB compositions from Réunion Island lavas as reported in Kurzweil et al. (2019, grey shaded area) are shown for comparison

\section{Discussion}

To trace the processes leading to the observed HFSE fractionations in the Indonesian lavas, our new HFSE and isotope data need to be considered in the context of previous data and models for the petrogenesis of Central Indonesian lavas (e.g., Whitford 1975; Varne 1985; Edwards et al. 1994; Stolz et al. 1996; Woodhead et al. 2001; Gertisser and Keller 2003). Especially the previously identified and well-documented along-arc variations of subduction components (Handley et al. 2011, 2014) can serve as a framework to interpret the new HFSE data and allow the assessment of the representativeness of our dataset. We thus aim to (1) identify any along- and across-arc variations

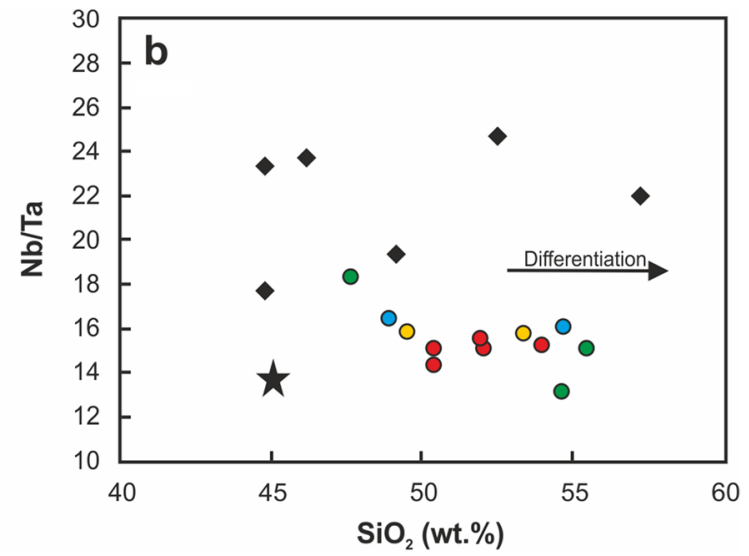

For neither the arc nor the rear-arc suite any changes of $\mathrm{Nb} / \mathrm{Ta}$ with increasing degree of differentiation are observed. Black star corresponds to PM composition after Palme and O'Neill (2014)

in HFSE compositions, (2) identify source compositions and mineralogies controlling HFSE fractionations, and (3) provide a basic genetic model that has to explain these geochemical characteristics within the larger framework of the Javanese plate configurations and input to the magmatic source(s).

\section{Source components in Sunda frontal arc lavas}

In general, the petrogenesis of the Sunda island arc volcanic rocks is influenced by (1) the composition of the asthenospheric mantle wedge, (2) the composition of subducted material (i.e., the oceanic plate and its sedimentary cover) that is known to exhibit strong regional variations (see Handley et al. 2011, and references therein), as well as (3) assimilation and fractional crystallization (AFC) during ascent or shallow-level AFC processes.

First, however, effects of crustal assimilation need to be assessed before evaluating the influence of subduction components on the relevant trace element and isotope signatures of the lavas. As shown for example in Fig. 2b, the $\mathrm{Nb}-\mathrm{Ta}$ ratios of the arc suite are largely unaffected by assimilation and fractional crystallisation processes, as no correlation with indices of mineral accumulation and fractional crystallisation are observed, in this case $\mathrm{Nb} / \mathrm{Ta}$ vs. $\mathrm{SiO}_{2}$. Although crustal assimilation has been inferred based on $\mathrm{Pb}-\mathrm{O}$ isotope compositions (Handley et al. 2014), virtually all potential assimilants along the Java frontal arc (ultramafic/ophiolitic rock sequences in West Java, carbonate sediments in Central Java) have low HFSE concentrations (data for basement compositions in Handley et al. 2014, and text below), thus precluding a significant impact on relevant HFSE ratios. For example, a major contribution of carbonate assimilation on the 

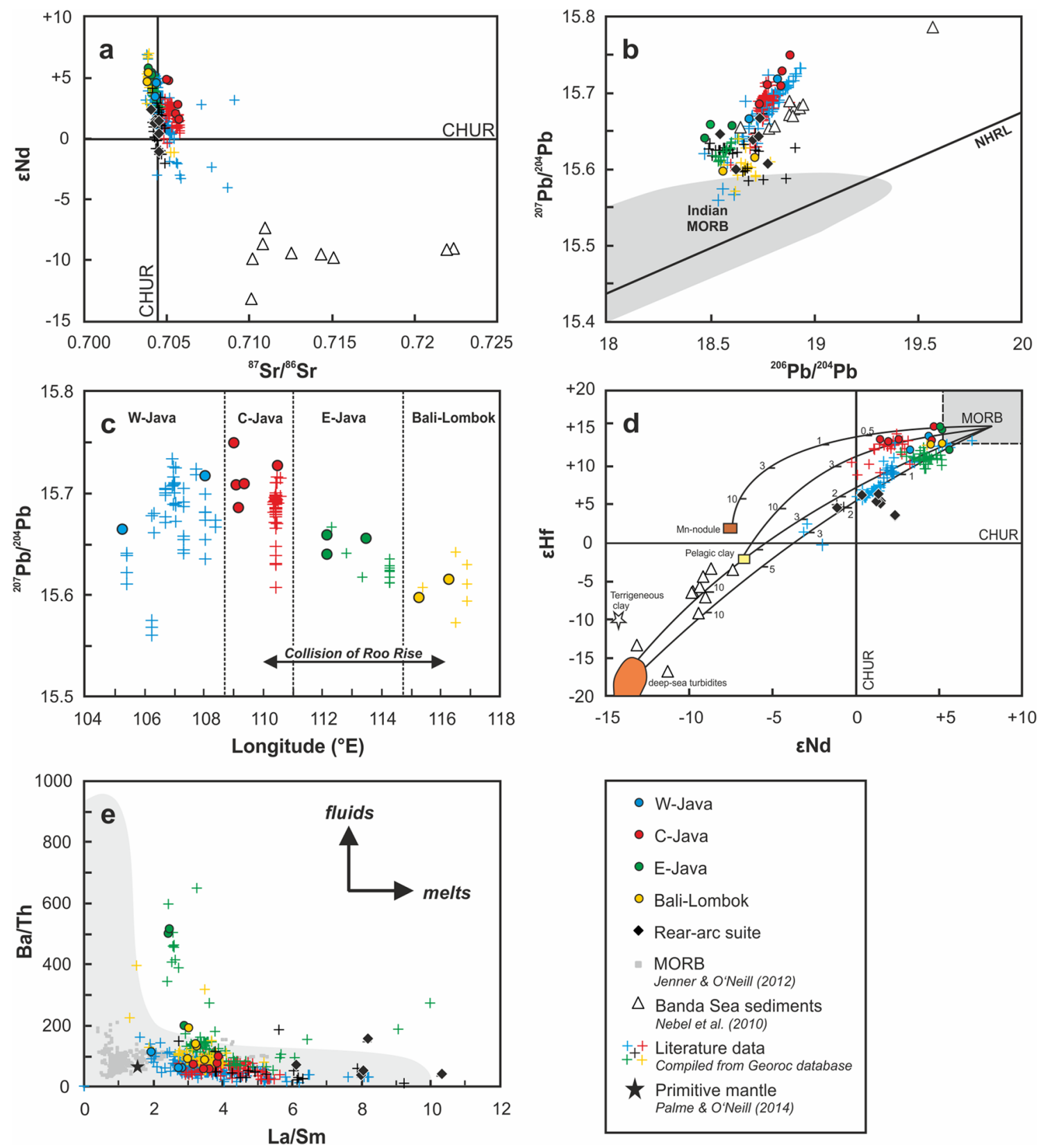

Fig. 4 Trace element and $\mathrm{Sr}-\mathrm{Nd}-\mathrm{Hf}-\mathrm{Pb}$ isotope compositions of the Sunda arc and rear-arc lavas in comparison to literature data for the study area as well as MORB (e.g. panels a and b). Except for some E-Java samples, most samples generally show a melt-like source enrichment that can be linked to a sediment input that varies along the Sunda arc. This is expressed in distinct $\mathrm{Pb}$ isotope compositions along the arc (c) as well as distinct Hf-Nd isotope compositions as a function of source input (d). While the rear-arc lavas overlap in most radiogenic isotope compositions with some arc segments, they how-

HFSE budget of the Central Java samples can be ruled out as data for marls of the crustal basement (Handley et al. 2014) indicate rather low HFSE contents and unradiogenic $\mathrm{Sr}$ isotope compositions $(\mathrm{Zr}<70 \mu \mathrm{g} / \mathrm{g}, \mathrm{Hf}<1.5 \mu \mathrm{g} / \mathrm{g} ; \mathrm{Zr} /$ $\left.\mathrm{Hf}=45 ;{ }^{87} \mathrm{Sr} /{ }^{86} \mathrm{Sr}=0.70433\right)$. Additionally, the $\mathrm{Hf}$ and $\mathrm{Nd}$

ever represent an enriched endmember regarding their trace element composition (e). Indian MORB after Hofmann (2014) and references therein, NHRL after Hart (1984); Literature data, if not indicated otherwise, are compiled from the Georoc database. Model lines as well as end-member compositions in $\mathbf{d}$ after Handley et al. (2011); e grey field represents a compilation of arc-lavas worldwide after Woodhead et al. (2001), the black star represents the primitive mantle (PM) after Palme and O'Neill (2014)

isotope compositions of the present samples overlap with those determined in previous studies, or are at the most radiogenic end for volcanic centres with limited available data (see Appendix Fig. 1). We thus consider our samples 
and their HFSE systematic suitable to constrain petrogenetic processes along the Sunda frontal arc.

The source input and type of source components in the Sunda arc are strongly related to tectonic configuration of the subduction zone. Whereas the mantle sources along the Sunda arc are purportedly very similar, i.e., an Indian MORB (I-MORB) type mantle, the subduction components along the arc are inferred to be quite heterogeneous (Handley et al. 2011, 2014). For example, the sediment type and mass deposited in the trench to the east and west of Java vary significantly along the entire Sunda arc: up to $5 \mathrm{~km}$ of sedimentary material fills the Sumatra Trench west of Java, less than $1 \mathrm{~km}$ in the western Java Trench and barely any trench sediments are inferred for the eastern Sunda Trench (Plank \& Langmuir 1998). The sediments deposited on the Indian Ocean Plate south of the trench are relatively uniform in thickness along the arc (200-400 m; Hamilton 1979; Moore et al. 1980; Plank and Langmuir 1998) and are predominantly pelagic (Hamilton 1979). Additionally, the subduction of the Roo Rise (110-116 $\left.{ }^{\circ} \mathrm{E}\right)$ imparts structural and geochemical variations on the source input, which are listed in detail below. The resulting change in subduction components (composition and/or mass) is directly reflected by discrete isotope and trace element patterns for each of the Java sectors. This can be showcased, for example, with $\mathrm{Pb}$ isotope variations along the arc (see Fig. 4c) that mirror a change in sediment component and/or mass being subducted and assimilated from more radiogenic in the West (Krakatoa being an exception) to more unradiogenic ${ }^{207} \mathrm{~Pb} /{ }^{204} \mathrm{~Pb}$ compositions in the East Java sector.

\section{West Java}

While crustal assimilation of more isotopically primitive arc rocks and/or ophiolitic crust was inferred by Handley et al. (2014) based on $\mathrm{Pb}$ and $\mathrm{O}$ isotope compositions, its impact on the geochemistry of the West Java lavas was considered to be minor. The sample from Galunggung (I3Ga1) is similarly depleted in its trace element budget as the East Java samples, whereas the samples from Krakatoa mostly overlap with Central Java trace element compositions. Furthermore, Hf-Nd isotope compositions (Fig. 4d) show that source contamination in West Java might be controlled by $<5 \%$ of more continental (turbiditic) material that is potentially derived from the Himalayan collision zone and from deep-sea fans surrounding India (Handley et al. 2011, 2014). The West Java samples from our study furthermore show distinct radiogenic isotope compositions ( $\mathrm{Sr}-\mathrm{Nd}-\mathrm{Hf}-\mathrm{Pb})$ in that, compared to the other sectors, they are plotting in between East Java and Central Java (Fig. $4 \mathrm{a}-\mathrm{c}$ ) as well as they have lower $\mathrm{La} / \mathrm{Sm}$
(Fig. 4e). Additionally, the samples from our study also plot at the most radiogenic end in $\varepsilon \mathrm{Hf}-\varepsilon \mathrm{Nd}$ space (Fig. 4d) compared to data for West Java given by Handley et al. (2011) and Woodhead et al. (2001).

\section{Central Java}

Our data combined with literature data indicate that Central Java samples tend to higher $\mathrm{La} / \mathrm{Sm}$ (and also higher $\mathrm{La}_{\mathrm{N}} /$ $\mathrm{Yb}_{\mathrm{N}}$ ) than West and East Java samples (Fig. 4e), which, together with the more radiogenic $\mathrm{Sr}$ isotope compositions, indicate a higher source overprint by melt-like sediment components. As shown in Fig. 3, the Central Java samples also display the highest incompatible trace element enrichment of the frontal arc suite, e.g., the highest positive $\mathrm{Pb}$ anomaly and LREE enrichment. Central Java lavas additionally have distinct Hf-Nd isotope compositions (Fig. 4d) that lie on a mixing line between Indian (I)-MORB and pelagic clay. The apparent decoupling of Hf-Nd isotope compositions might be due to bulk mixing with more clay-rich sediment or because of the higher mobility of Nd in subduction components (Pearce et al. 1999; Woodhead et al. 2001; Hermann and Rubatto 2009). As illustrated in Fig. 4, our samples show a good overlap with literature data from Handley et al. (2011) and Woodhead et al. (2001). Whereas the Hf isotope compositions of Central Java are quite similar to the other sectors, $\mathrm{Nd}$ and $\mathrm{Sr}$ isotopes are offset to less radiogenic and more radiogenic compositions, respectively, relative to West and East Java samples. Higher $\delta^{18} \mathrm{O}$ together with the more radiogenic $\mathrm{Sr}$ isotope compositions were previously attributed to shallow level assimilation of crustal carbonate/ limestone, as was, e.g., previously shown for Merapi (Chadwick et al. 2007; Deegan et al. 2010; Troll et al. 2013).

\section{East Java and Bali-Lombok}

Compared to subduction accretion in the Western and Central sectors, the basement to the east is subjected to pronounced subduction erosion (Kopp et al. 2006) due to the subduction of the Roo Rise. Previous work (Handley et al. 2011, 2014) showed little evidence for crustal assimilation, but a higher proportion of fluid-like subduction components and incorporation of detrital-poor (clay-rich) pelagic sediments, which is evident from fluid mobility proxies, e.g., higher $\mathrm{Ba} / \mathrm{Th}$ and lower $\mathrm{La} / \mathrm{Sm}$ (Fig. 4e), and the most radiogenic $\mathrm{Hf}-\mathrm{Nd}$ and most unradiogenic $\mathrm{Sr}-\mathrm{Pb}$ isotope compositions of the Sunda data set (Fig. 4a, b). Additionally, East Java samples are the most depleted samples with the highest depletion of $\mathrm{Nb}-\mathrm{Ta}$ and the highest enrichments in fluid-mobile elements like $\mathrm{Ba}, \mathrm{U}$, or $\mathrm{Pb}$, relative to less fluidmobile elements of similar incompatibility (Fig. 3). 

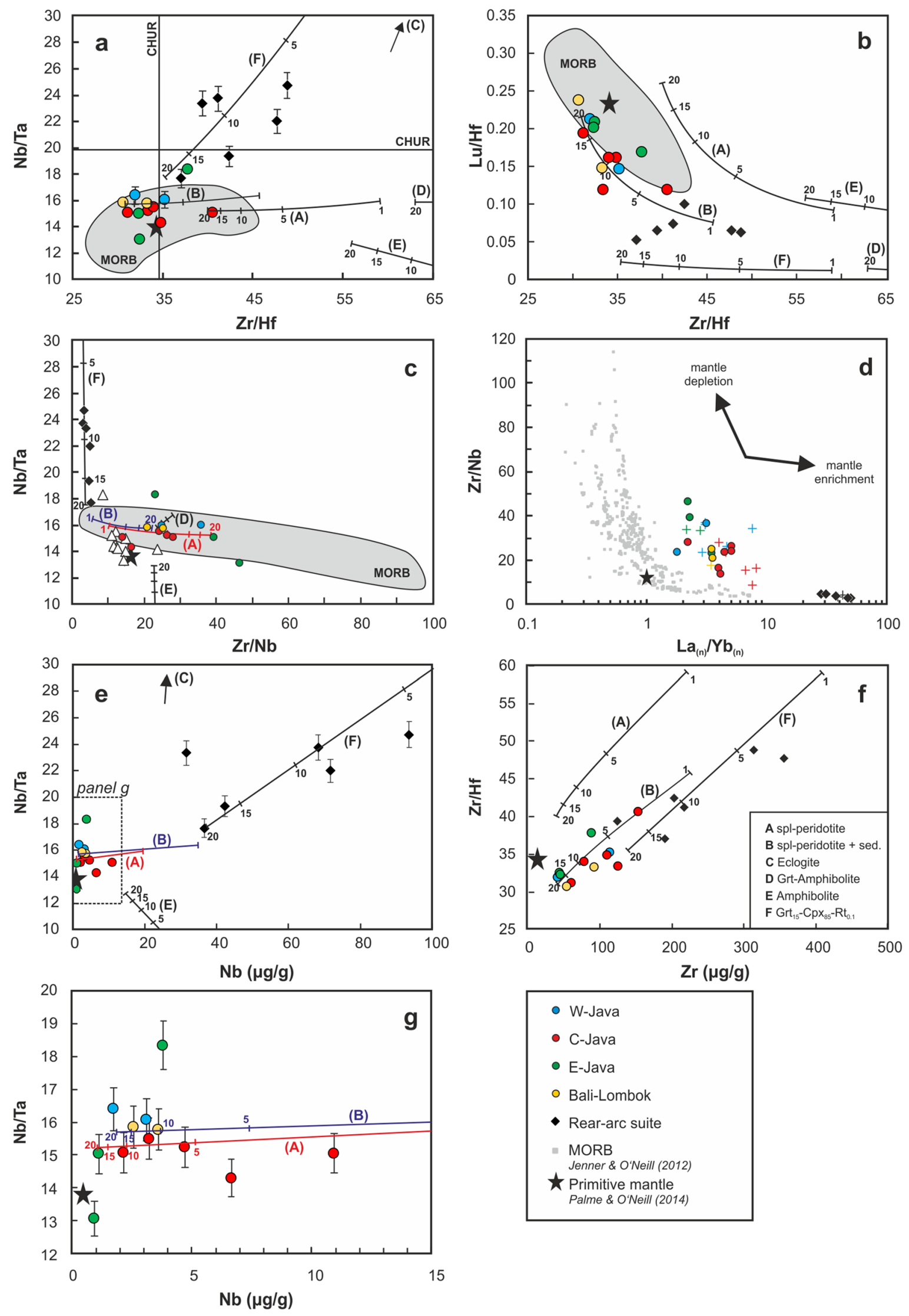

$$
\begin{aligned}
& \text { - W-Java } \\
& \text { - C-Java } \\
& \text { - E-Java } \\
& \text { - Bali-Lombok } \\
& \text { - Rear-arc suite } \\
& \text { - MORB } \\
& \text { Jenner \& O'Neill (2012) } \\
& \text { Primitive mantle } \\
& \text { Palme \& O'Neill (2014) }
\end{aligned}
$$


4Fig. 5 Mantle sources of the Sunda arc and rear-arc lavas inferred from HFSE data and (non-modal) batch melting modelling. The HFSE composition of the frontal arc lavas is best reproduced by melting of a sediment-enriched spinel peridotitic source (model line B). The sediment component in model B strongly influences $\mathrm{Zr} / \mathrm{Hf}$, Lu/ $\mathrm{Hf}$ and $\mathrm{Zr} / \mathrm{Nb}(\mathbf{a}, \mathbf{b}, \mathbf{f})$, while $\mathrm{Nb} / \mathrm{Ta}$ shows only marginal differences to the sediment-free and sediment-bearing source melting (models A and B, see $\mathbf{g}$ ). The rear-arc lavas partly display high superchondritic $\mathrm{Nb} / \mathrm{Ta}$, which are in agreement with partial melting in the eclogite stability field (grt15-cpx85) containing $0.1 \%$ rutile $(\mathbf{a}, \mathbf{c}, \mathbf{e})$ of an HFSE and trace element enriched source $(\mathbf{d}, \mathbf{e}, \mathbf{f})$. Colour code as in Fig. 4. MORB after Jenner and O'Neill (2012; d) and as in Münker et al. (2004) in panels a-c. Symbols as in Fig. 4

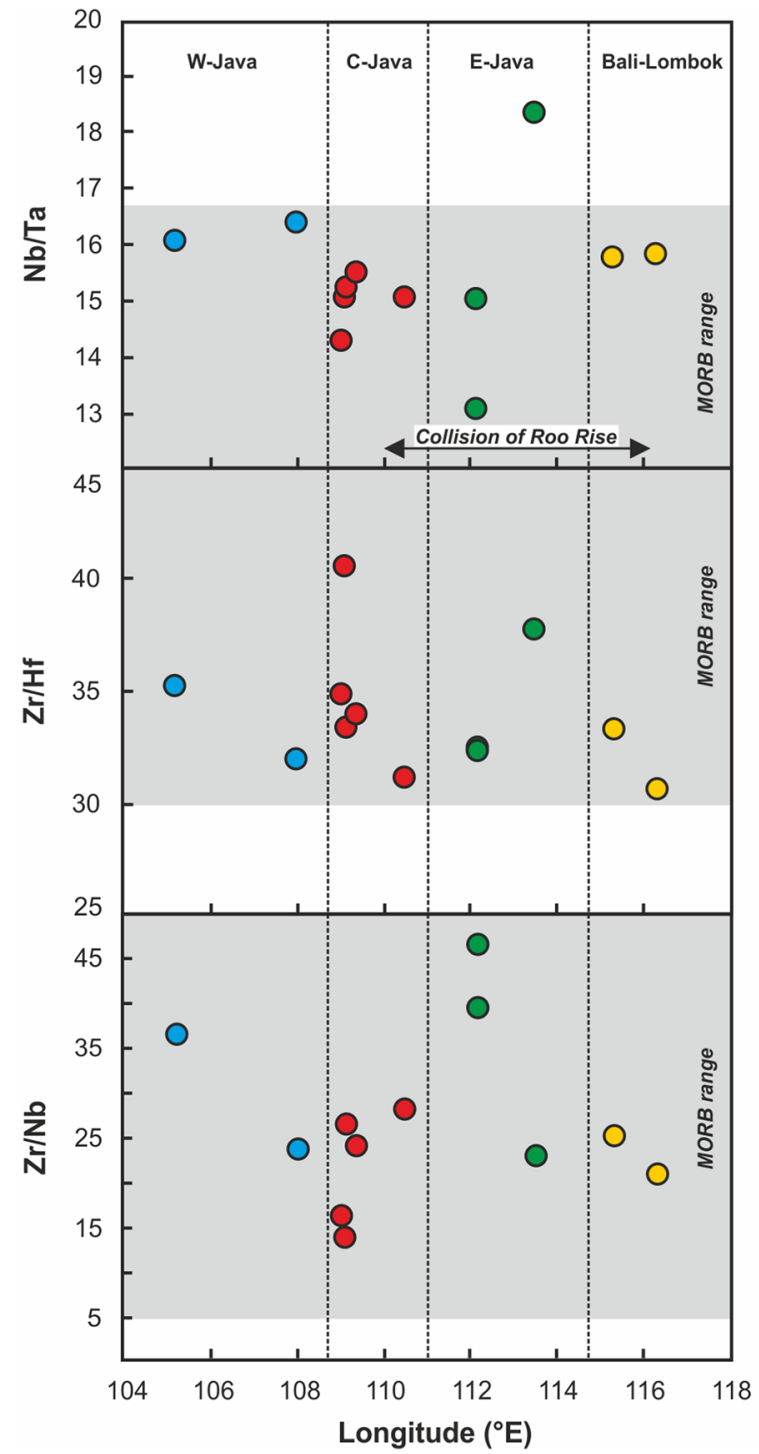

Fig. 6 Along-arc variations of relevant HFSE-W ratios. Most HFSE ratios like $\mathrm{Nb} / \mathrm{Ta}, \mathrm{Zr} / \mathrm{Hf}$ and $\mathrm{Zr} / \mathrm{Nb}$ show little variation outside the range previously determined for MORB, albeit some inter-segment variations are observed, e.g. for the Central and East Java samples. Ratios involving W show more variation, which is interpreted to be

\section{Partial melting model}

Based on the considerations above, it becomes obvious that at least three source components are required to account for the trace element and isotope budget of the frontal and rear-arc lavas from Java: depleted mantle, subducted sediments from the Australian plate, and components derived from the mafic portions of the subducting slab. To further quantify and constrain source compositions and-variations of the Sunda frontal arc and rear-arc lavas, we, therefore, modelled sub-arc partial melting, focussing on the HFSE and their ratios. Modelling details and input parameters

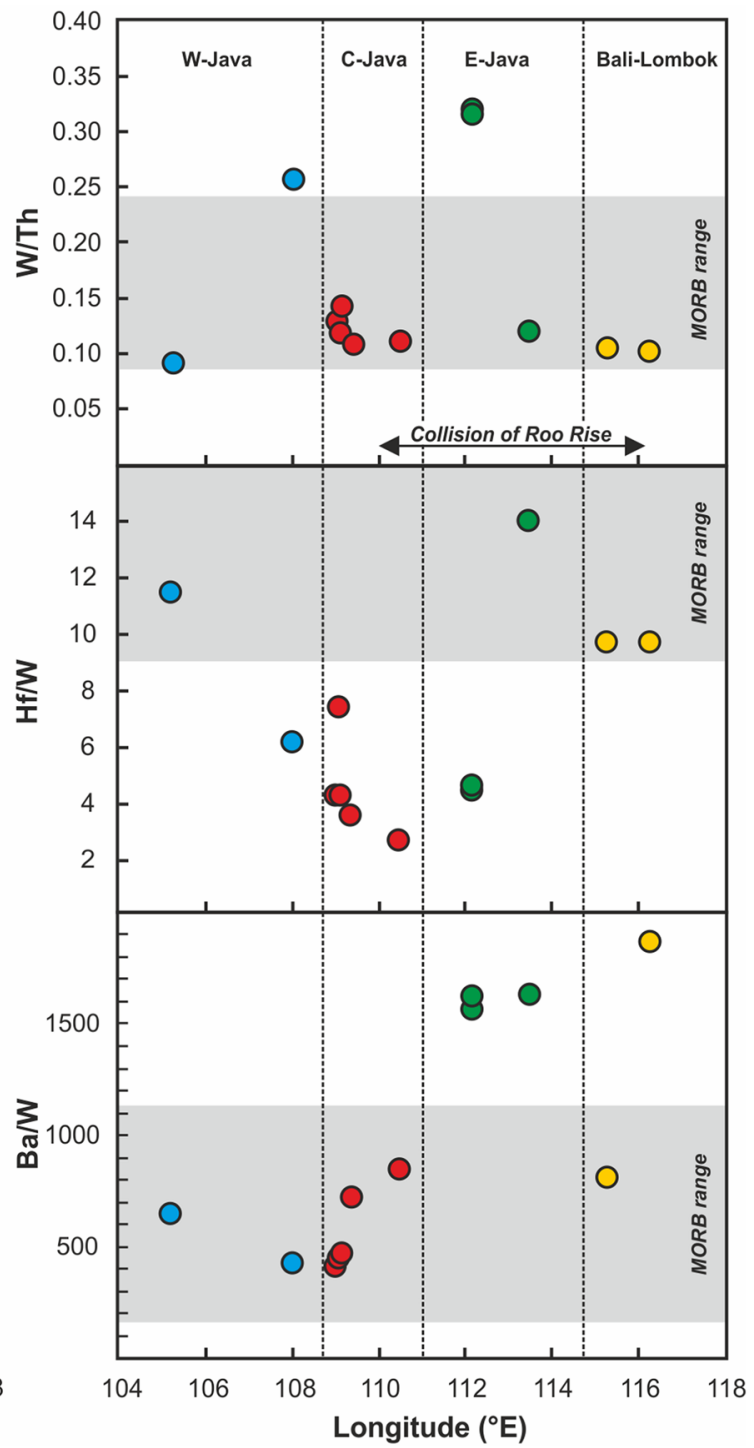

due to an enrichment by a sediment component in some (Hf/W, W/ Th) and fluid release in others (e.g., Ba/W). MORB data are from Jenner and O’Neill (2012), Gale et al. (2013), König et al. (2011), and as outlined in Münker et al. (2004) 

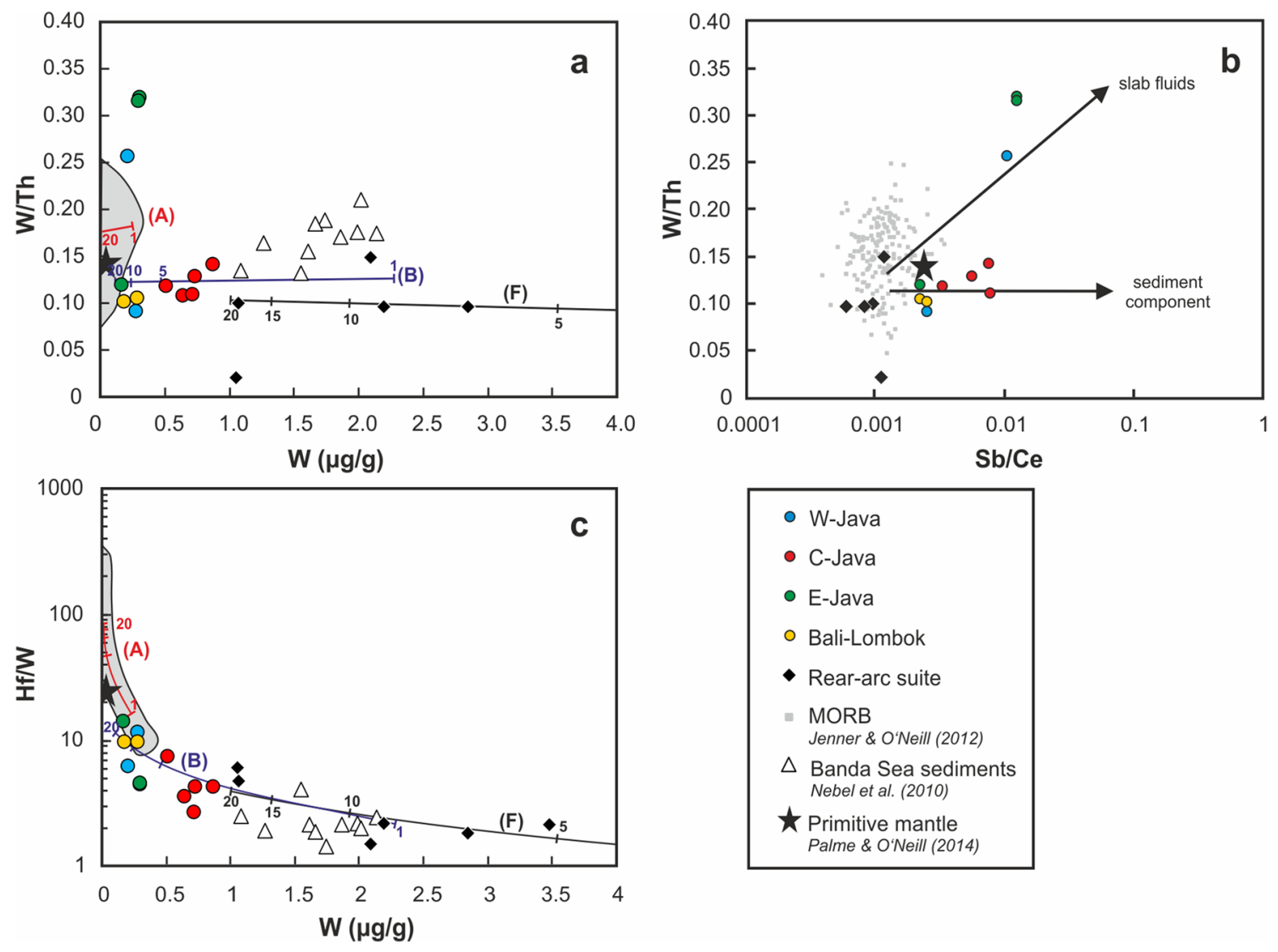

Fig. 7 Constraining subduction components using ratios of W-Th-Hf and $\mathrm{Sb} / \mathrm{Ce}$. Model curves labelled as in Fig. 5. For both the frontal and the rear-arc lavas the $\mathrm{W}$ systematics show the influence of a meltlike component that leaves W/Th relatively unfractionated (a and b) apart from one rear-arc sample (I16Mu6) that shows low W/Th and

such as mineral modes and starting compositions, partition coefficients and their respective references can be found in Appendix D. For the frontal arc lavas, we modelled partial melting of (A) a depleted spinel-peridotite mantle source with a slightly modified composition as the one reported by Salters and Stracke (2004). Model (A) serves as a comparison framework for MORB melting without the involvement of a sediment component. As such, we used model (B) of a spinel-peridotitic source enriched by sediment-like subduction components ( $2 \%$ bulk mixing of pelagic clay into the depleted mantle source), both followed by non-modal batch melting. For the frontal arc lavas, we broadly followed the parameterization of Handley et al. (2011), who showed the $\mathrm{Hf}-\mathrm{Nd}$ isotope composition of most of the West and Central Java lavas to be in agreement with addition of $2-3 \%$ bulk pelagic clay or deep sea turbidites. The bulk sediment mixing model as employed here does not distinguish between fluid- and melt-related source enrichment of specific elements, but given the virtual immobility of the HFSE in subduction zone fluids, the bulk mixing model can still provide two samples from E-Java and one from W-Java extending to higher $\mathrm{W} / \mathrm{Th}$. The modelling supports the view that $\mathrm{W}$ was added to the source of both the frontal and rear-arc lavas (models B and F) compared to a DM source (model A), which is also emphasized in panel (c) of $\mathrm{Hf} / \mathrm{W}$ vs. W concentration

valuable information about source composition—enrichment and-melting processes.

To illustrate the influence of variable source overprint by slab melts derived from mafic portions of subducting oceanic crust on the HFSE and trace element inventory of the rear-arc lavas, we modelled addition of slab melts formed at different $\mathrm{P}-\mathrm{T}$ conditions from mafic protoliths of basaltic composition: (C) Ti-rich, rutile-bearing eclogite, (D) grtamphibolite, (E) amphibolite, as well as low-Ti rutile-bearing eclogite $(\mathrm{F})$. The latter is a grt-pyroxenite (15:85 grt:px) containing $0.1 \%$ rutile with a HFSE composition transitional between $\mathrm{N}$ - and E-MORB or, alternatively a depleted source mixed with various proportions of pelagic sediment. Similar to models A and B for the frontal arc lavas, we used a batch melting model with source and modal compositions as well as partition coefficients as reported in Appendix C. The selection of appropriate partition coefficients for some HFSE was sometimes hampered by incomplete datasets for some mineral/melt composition, particularly those at elevated $\mathrm{P}-\mathrm{T}$ conditions. Hence, some ratios could not be modelled and 
were omitted for the respective compositions. Results of the model calculations are illustrated in Figs. 5, 7, and 8.

\section{Frontal arc along-strike HFSE variations}

Although Handley et al. (2011, 2014) suggested a rather homogenous mantle source along the Sunda arc, mainly based on radiogenic isotope compositions, HFSE variations in conjunction with $\mathrm{Sr}-\mathrm{Nd}-\mathrm{Hf}-\mathrm{Pb}$ isotopes along the arc might shed further light on mantle source compositions and input of subduction components along the arc. As such, critical HFSE ratios to assess potential source variations of the frontal arc lavas are shown in Fig. 5 compared to the rear-arc suite and MORB, and in Fig. 6 for the arc samples with respect to their latitudinal position. Owing to the compatibility order of $\mathrm{Nb} \leq \mathrm{Ta}<<\mathrm{Zr} \leq \mathrm{Hf}<<\mathrm{Lu}$ (e.g., Weyer et al. 2003; McDade et al. 2003), partial melting results in melts that follow trends as roughly outlined by MORB compositions. Consequently, any offset of a sample suite from the MORB array in a specific HFSE ratio indicates selective addition of the respective HFSE during sub-arc mantle enrichment by subduction components, depletion during previous melting events or by the selective retention by refractory HFSE-rich phases (see previous studies by Weyer et al. 2003; Münker et al. 2004; König et al. 2008; Kirchenbaur and Münker 2015).

Although a comparatively limited dataset is presented here for the Sunda frontal arc suite, the samples can be considered representative and put into the context of previously described mantle source variations along the arc. The entire frontal arc suite lies at the lower end of typical MORB compositions in $\mathrm{Nb} / \mathrm{Ta}-\mathrm{Zr} / \mathrm{Hf}$ space (Fig. 5a). There are barely any variations of $\mathrm{Nb} / \mathrm{Ta}$ between the individual arc segments and their $\mathrm{Nb} / \mathrm{Ta}$ also cover a similar range to local sediments from the Banda arc (Nebel et al. 2010). An exception here is the East Java suite where the three samples cover a $\mathrm{Nb} / \mathrm{Ta}$ range from 13 to 18, still in agreement with the data from Woodhead et al. (2001). In Lu/Hf vs. Zr/Hf space (Fig. 5b), the Central- and West-Java as well as the Bali-Lombok samples are shifted towards lower Lu/Hf than MORB, and the East Java samples overlap with the lower end of the MORB array. The modelling performed above essentially shows that the relevant HFSE ratios $\mathrm{Nb} / \mathrm{Ta}, \mathrm{Zr} / \mathrm{Hf}, \mathrm{Zr} / \mathrm{Nb}$, Hf/W, W/Th as well as the HFSE concentrations of the frontal arc lavas (see Figs. 5, 7, 8) can be well reproduced for the sedimentenriched source composition (model B). Melting degrees are in the range of $\sim 3-20 \%$, which is in agreement with general estimates for sub-arc melting in island arc settings (e.g. Hawkesworth et al. 1993). In line with the observations for $\mathrm{Zr} / \mathrm{Nb}$ and $\mathrm{Nb} / \mathrm{Ta}$ for the East Java suite, the modelling also confirms the derivation of these samples from more depleted sources compared to the other arc segments. The data and modelling potentially mirrors the Indian (I)-MORB mantle as a source, which is also reflected in their $\mathrm{Hf}-\mathrm{Nd}$ isotope compositions that overlap with purported I-MORB mantle values (see Handley et al. 2011). As such, the East Java samples also lie at the most depleted end in $\mathrm{Zr} / \mathrm{Nb}$ vs. $\mathrm{Nb} / \mathrm{Ta}$ or $\mathrm{La}_{\mathrm{N}} / \mathrm{Yb}_{\mathrm{N}}$ (Fig. 5c, d).

While the modelling shows that $\mathrm{Nb} / \mathrm{Ta}$ is not overly sensitive to sediment addition, $\mathrm{Zr} / \mathrm{Hf}$ is significantly affected and provides a far better fit for the sediment involved melting model (model B) compared to model A where melting of pure, depleted spinel-peridotite is assumed. For the frontal arc lavas, large effects of cpx fractionation on $\mathrm{Zr} / \mathrm{Hf}$ can be excluded due to the lack of a negative co-variation with $\mathrm{Sc}$ that would otherwise be expected in this case (David et al. 2000). As the spread of $\mathrm{Zr} / \mathrm{Hf}$ in the Central Java samples correlates positively with $\mathrm{Sr}$ isotopes, we consider this as further evidence for the contribution of a sediment melt to their mantle source.

Further insight into fluid-mediated source processes and sediment involvement can be provided by $\mathrm{W}$ systematics. In the absence of metal phases or sulphides, $\mathrm{W}$ behaves as a highly incompatible lithophile element during partial melting, similar to Th, Ba, or U (e.g., Palme \& Rammensee 1981; Newsom et al. 1996). Tungsten is part of the extended HFSE group and considered fluid-mobile in subduction zones, similarly to, albeit slightly less mobile than $\mathrm{Ba}$ (König et al. 2008). Particularly in arcs with a high flux of sediments, elevated W/Th or fractionated W/Ba are found (König et al. 2008; Kirchenbaur and Münker 2015), arguing for an increased mobility of $\mathrm{W}$ compared to the purported similarly incompatible elements. Surprisingly, ratios of W/ Th are quite invariant along the Sunda arc (Fig. 7c) and mainly overlap typical canonical compositions as displayed by MORBs and OIBs (ca. 0.15, König et al. 2011). Only two samples from East Java exceed the range for MORB, and these are also the samples that record the highest fluid contribution as evident from, e.g., high $\mathrm{Ba} / \mathrm{La}$ in combination with low $\mathrm{La} / \mathrm{Sm}$ (Fig. 4e). In a plot of W/Th vs. Sb/Ce (Fig. 7b), the highest fluid contributions are also revealed by the East Java samples and potentially also the sample from Galunggung. Other relevant trace element ratios involving W (Hf/W, Ba/W; see Fig. 6) show significant difference between West and Central Java, and East Java and BaliLombok. West and Central Java show successively decreasing $\mathrm{Hf} / \mathrm{W}$ and $\mathrm{Ba} / \mathrm{W}$, while opposite trends are observed for the Eastern part of the Sunda arc. The higher $\mathrm{Ba} / \mathrm{W}$ in the East Java suite are again in agreement with the higher purported fluid contribution as $\mathrm{Ba}$ is more fluid mobile than $\mathrm{W}$, whereas the lowest $\mathrm{Ba} / \mathrm{W}$ are found in the more sedimentdominated samples from Central Java and Galunggung. From the modelling it becomes obvious that the $\mathrm{W}$ budget in the frontal arc lavas is to a large degree controlled by the sediment component, which is showcased in Fig. 7 of Hf/W vs. W and W/Th vs. W. We estimate that the mass fractions 

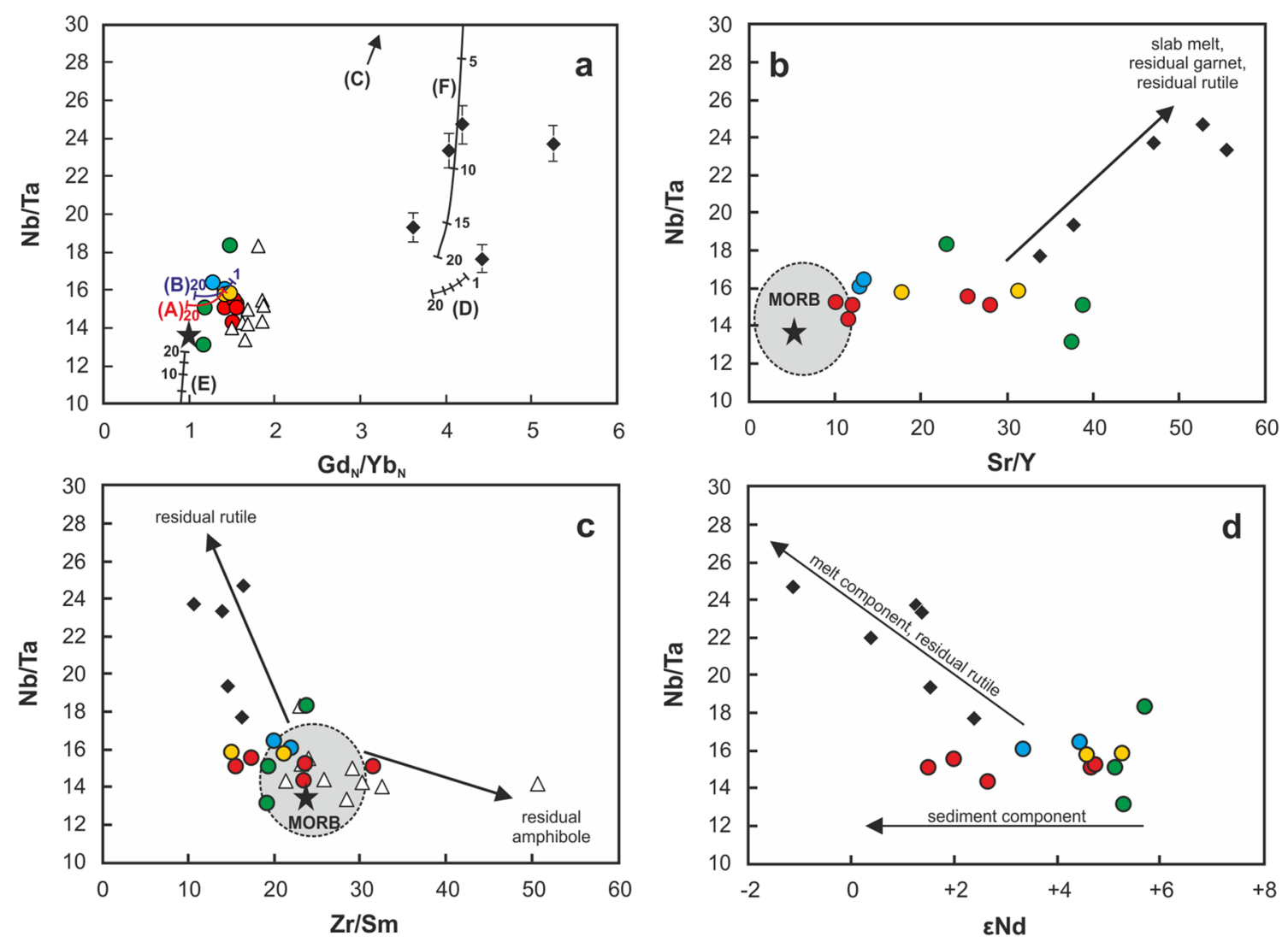

Fig. 8 For the rear-arc lavas, a slab melt contribution can be demonstrated using $\mathrm{Nb} / \mathrm{Ta}$ in combination with indicators for relevant residual slab mineralogies like garnet $\left(\mathrm{Gd}_{\mathrm{N}} / \mathrm{Yb}_{\mathrm{N}}, \mathrm{Sr} / \mathrm{Y} ; \mathbf{a}\right.$ and $\left.\mathbf{b}\right)$ or residual rutile $(\mathrm{Zr} / \mathrm{Sm}$; c). The negative correlation of $\mathrm{Nb} / \mathrm{Ta}$ with $\varepsilon \mathrm{Nd}(\mathbf{d})$ and batch melting model lines in panel a highlight the source enrichment

of the rear-arc lavas by a melt generated in the garnet-stability field in the presence of residual rutile. Symbols and model lines as in Figs. 4, 5, and 7. MORB after Jenner and O'Neill (2012), Büchl et al. (2002), Münker et al. (2004). Vectors are as given in Hoffmann et al. (2011) and König and Schuth (2011)

of $\mathrm{W}$ in the frontal arc suite sources need to be enriched by a factor of $\sim 10$ compared to the DM value of $0.0024 \mu \mathrm{g} / \mathrm{g}$ (König et al. 2011). In our model, this is accomplished by mixing $2 \%$ of pelagic clay with a W content of $1.66 \mu \mathrm{g} / \mathrm{g}$ (local pelagic clay, Nebel et al. 2010) to the mantle source. However, the co-variation in the Central Java samples of e.g., $\mathrm{Ba} / \mathrm{W}$ with $\mathrm{Hf} / \mathrm{W}$, which can be inferred from Fig. 6, might indicate that the $\mathrm{W}$ enrichment rather involved fluidlike components with high $\mathrm{Ba} / \mathrm{W}$ and low $\mathrm{Hf} / \mathrm{W}$ derived from the subducted pelagic clays. This is further supported, for example, by Hf-Nd isotope systematic (Fig. 4d).

\section{Rear-arc variations}

Only limited geochemical data are available for the rear-arc volcanoes for a comparison to our new data (Whitford 1975; Nicholls and Whitford 1983; Edwards et al. 1994; Vukadinovic 1995; Woodhead et al. 2001). Generally, all literature data agree very well with our data for the rear-arc volcanism and share the common consensus that the rear-arc lavas are derived from distinct and more enriched mantle sources

compared to the frontal arc volcanism. The enriched nature of the rear-arc mantle source is evident in the strong enrichment of incompatible elements for which examples are the high La/Sm (> 6; Fig. 4e) or $\mathrm{La}_{\mathrm{N}} / \mathrm{Yb}_{\mathrm{N}}$ (up to 48; Fig. 5d), together with elevated $\mathrm{K}_{2} \mathrm{O}$ contents (up to $5.50 \mathrm{wt}$.\%). The trace element patterns of the rear-arc suite are reminiscent of intraplate/OIB type lavas for which Réunion samples are given as an example in Fig. 3. The rear-arc samples share some geochemical characteristics with OIB lavas such as enrichment in incompatible trace elements (e.g., Ba, Th, K, $\mathrm{Nb}$ ) without any apparent $\mathrm{Pb}$ anomaly (see Fig. 3). However, the rear-arc lavas exhibit $\mathrm{Nb}-\mathrm{Ta}$ and $\mathrm{Zr}-\mathrm{Hf}$ troughs and low $\mathrm{Nb} / \mathrm{U}$ (9-17), which are unusual for intraplate/OIB lavas and more typical of subduction-related lavas. Albeit being highly enriched in elements like $\mathrm{Ba}$ or $\mathrm{Sr}$ the samples show no indication of pronounced fluid-like source components as they have very low ratios like $\mathrm{Ba} / \mathrm{Th}, \mathrm{Ba} / \mathrm{La}$ (not shown), and $\mathrm{Sb} /$ Ce (Figs. 4, 7). The rear-arc suite samples also do not deviate in their radiogenic isotope compositions from the frontal arc suite samples as would be expected from lavas originating from an OIB source, particularly regarding the $\mathrm{Sr}-\mathrm{Pb}$ 
isotope composition (Figs. 4b, 7c, d). Nevertheless, the reararc samples display slightly less radiogenic $\mathrm{Hf}-\mathrm{Nd}$ isotope compositions compared to the frontal arc suite (Fig. 4d). To explain these hybrid geochemical characteristics, previous studies (e.g., Edwards et al. 1994) inferred a transition from an intraplate setting (decompression melting) to subduction-overprinted sources, which results in low $\delta^{18} \mathrm{O}$, extreme trace element enrichment and distinct $\mathrm{Sr}-\mathrm{Nd}-\mathrm{Pb}$ isotope compositions. These potential endmembers will be further evaluated below using the HFSE systematics of the rear-arc lavas in comparison to those of the frontal arc suite combined with trace element modelling addressing which source component can account for compositions of the reararc lavas.

As stated above, a distinct, more enriched mantle source for the rear-arc lavas is evident from trace element compositions, but also from the HFSE systematics presented here and in the literature (e.g., Vukadinovic 1995). Low $\mathrm{Zr} / \mathrm{Nb}$ $(<10)$ as well as a clear displacement from the MORB array in $\mathrm{Lu} / \mathrm{Hf}$ vs. $\mathrm{Zr} / \mathrm{Hf}$ space (Fig. 5b) argues for a more enriched mantle source that is distinct from a typical mantle melting trend as exemplified by model A (depleted spinel peridotite). However, one of the most striking differences between the frontal arc and the rear-arc suite are the superchondritic $\mathrm{Nb} /$ Ta in the rear-arc suite. As noted early on, the Sunda arc is one of the key localities worldwide where superchondritic $\mathrm{Nb} / \mathrm{Ta}$ (i.e. $>20$ ) were previously observed in an arc setting (Stolz et al. 1996). These authors also attributed $\mathrm{Nb} /$ Ta $>20$ to source hybridization by silicic melts derived from the subducted slab. More recently, $\mathrm{Nb}-\mathrm{Ta}$ fractionation was also linked to their transport in supercritical fluids (Kessel et al. 2005; Chen et al. 2018). Average arc volcanism requires sub-arc melting at pressures corresponding to depths of $120-180 \mathrm{~km}$ at temperatures in the range of $700-1200{ }^{\circ} \mathrm{C}$. Conversely, supercritical liquids occur at $\mathrm{P}-\mathrm{T}$ conditions above the second critical end point of a $\mathrm{H}_{2} \mathrm{O}$-silicate system (1.5-3.8 GPa and $900-1150{ }^{\circ} \mathrm{C}$; Mibe et al. 2007; Chen et al. 2018), where the miscibility gap between silicate melt and aqueous fluid diminishes (Kessel et al. 2005; Chen et al. 2018). Generation of slab melts from mafic protoliths is anticipated to occur over $\mathrm{P}-\mathrm{T}$ ranges where garnet is stable, i.e., in amphibolite- or eclogite-facies conditions (e.g., Ringwood 1976; Yogodzinski et al. 2001; Macpherson et al. 2006), and thus giving rise to silica-rich partial melts that react with the overlying mantle wedge to produce pyroxenites (e.g., Yaxley and Green 1998). Typical slab-melt signatures include elevated $\mathrm{Sr} / \mathrm{Y}(>30), \mathrm{La}_{\mathrm{N}} / \mathrm{Yb}_{\mathrm{N}}$ and $\mathrm{Gd}_{\mathrm{N}} / \mathrm{Yb}_{\mathrm{N}}(>>1)$, owing to the preferential incorporation of the heavy REE into residual garnet (e.g., Hauri et al. 1994; van Westrenen et al. 1999). A garnet-source signature is well known for the rear-arc samples from Indonesia and has already been described in early studies (Whitford 1975; Nicholls and Whitford 1983) and further co-variations of Lu/
Hf with $\varepsilon \mathrm{Hf}, \mathrm{Nb} / \mathrm{Ta}$ with $\mathrm{La}_{\mathrm{N}} / \mathrm{Yb}_{\mathrm{N}}$ or $\mathrm{Gd}_{\mathrm{N}} / \mathrm{Yb}_{\mathrm{N}}$ (the latter is shown in Fig. 8a) support a slab melt control on the HFSE budget. The trace element modelling further confirms that only slab melts from high-pressure lithologies containing garnet (models C, D, F) are able to reproduce sufficiently elevated $\mathrm{Gd}_{\mathrm{N}} / \mathrm{Yb}_{\mathrm{N}}$ values in the range of those of the reararc samples, i.e.> 3.5. However, a perfect fit for the $\mathrm{Gd}_{\mathrm{N}} /$ $\mathrm{Yb}_{\mathrm{N}}$ values of the rear-arc samples was not achieved with either of the three models, which can either be caused by the choice of partition coefficients for the HREE in garnet or that an additional mobilization of the HREE took place during sub-arc mantle enrichment.

During both slab melting or the release of a supercritical fluid, the accessory mineral phase essentially controlling the $\mathrm{Nb}-\mathrm{Ta}$ budget in both cases is rutile. Rutile has been demonstrated to fractionate $\mathrm{Nb} / \mathrm{Ta}$ to higher values compared to MORB in the partial melt during both slab melting and supercritical fluid release when present as a residual phase (Foley et al. 2000; Green 1995; Klemme et al. 2002; Rudnick 2000; Stalder et al. 1998; Xiong et al. 2005; Kessel et al. 2005; Chen et al. 2018). Conversely, during shallower slab-melting in the garnet-amphibolite stability field, much of the HFSE budget is controlled by low-Mg amphibole, which has been suggested to yield in lower $\mathrm{Nb} / \mathrm{Ta}(<15)$ in the partial melt (Foley et al. 2002). Additionally, partial melts in equilibrium with residual rutile result in lower W/ $\mathrm{Th}$ or $\mathrm{Zr} / \mathrm{Sm}$ due to the preferential incorporation of Ta, $\mathrm{W}$ and $\mathrm{Zr}$ in rutile (Brenan et al. 1994; Foley et al. 2000; Zack et al. 2002; Klemme et al. 2005; Bali et al. 2012). As such, the $\mathrm{Nb}-\mathrm{Ta}$ systematics in combination with other trace element ratios (e.g., W/Th) and modelling of different source compositions is highly suited to distinguish between residual (low-pressure) amphibole (amphibolite) and high-pressure rutile (eclogite) during partial slab melting.

The combined results from the trace element modelling indicate that a small fraction of rutile $(\sim 0.1-0.5 \%)$ is already sufficient in the source of the slab melt overprinting the sources of rear-arc lavas to reproduce their high $\mathrm{Nb} / \mathrm{Ta}$. The general fit for some of the modelled curves is not perfect, e.g., for $\mathrm{Gd}_{\mathrm{N}} / \mathrm{Yb}_{\mathrm{N}}$ as mentioned above; however, it is clear that only a combination of rutile + garnet present during slab melting yields the spread of the rear-arc lavas. Particularly the modelled trend in $\mathrm{Nb} / \mathrm{Ta}$ vs. $\mathrm{Zr} / \mathrm{Hf}$ space (Fig. 5a) exclude a (garnet-)amphibolite source for the rear-arc lavas as well as a Ti-rich eclogitic source. The starting composition of the best-fit modelling of the rear-arc lavas (lowTi eclogite, model F) is that of an HFSE enriched source (see Appendix D), which is necessary to reproduce the high HFSE concentrations of the rear-arc lavas as it becomes obvious from the modelling of $\mathrm{Nb} / \mathrm{Ta}$ vs. $\mathrm{Nb}$ concentration (Fig. 5e) or $\mathrm{Zr} / \mathrm{Hf}$ vs. $\mathrm{Zr}$ (Fig. 5f). Furthermore, as shown above, the high $\mathrm{Nb} / \mathrm{Ta}$ of the rear-arc lavas can only be the result of a melt generated in the presence of residual rutile. 
The negative correlation of $\mathrm{Nb} / \mathrm{Ta}$ with $\varepsilon \mathrm{Nd}$ (Fig. 8d) and $\varepsilon H f$ (not shown), therefore, confirms a hybrid melt resulting from the tapping of the mafic portions of the slab in the eclogite stability field and a melt derived from subducted sediments generated in the presence of residual rutile.

Further information regarding the discrimination of melt vs. fluid source enrichment processes can be extracted from $\mathrm{W}-\mathrm{Th}$ systematics. The W/Th of the rear-arc lavas mostly overlap the lower end of the MORB array with one sample trending to even lower W/Th of 0.021 (I16Mu6) as it would be expected for slab melts with residual rutile (Fig. 7a, b). The fact that a rutile signature is not more prominently featured in the $\mathrm{W}$ systematics might be due to the $\mathrm{W}$ budget being controlled by the different subduction components in the rear-arc lavas, i.e., also by the subducted sediment components with their elevated W contents of ca. $1-2 \mu \mathrm{g} / \mathrm{g}$ (Nebel et al. 2010). The rear-arc lavas are relatively enriched in $\mathrm{W}$ (up to $3.5 \mu \mathrm{g} / \mathrm{g}$ in sample I15Mu5), which can be reconciled in our modelling (model F) with a source containing about $0.21 \mu \mathrm{g} / \mathrm{g} \mathrm{W}$ with a W/Th of 0.11 . The source of the rear-arc lavas thus likely requires the presence of subducted sediments rich in $\mathrm{W}$ as, e.g., reported for sediments drilled SE of Java (W of up to $3.5 \mu \mathrm{g} / \mathrm{g}$; Kurzweil et al. 2019), in the Banda Sea (W of up to $2.1 \mu \mathrm{g} / \mathrm{g}$; Nebel et al. 2010), or the Eastern Mediterranean (W of up to $1.2 \mu \mathrm{g} / \mathrm{g}$; Kirchenbaur and Münker 2015). In summary, the geochemistry as well as partial melting modelling of the rear-arc lavas indicate a mantle source that has been overprinted by both sediment melts and by a slab melt generated in the eclogite stability field.

\section{Tectonic-petrogenetic model for the rear-arc volcanism and the across-arc variation}

Several petrogenetic models have been put forward to explain the nature of the Java rear-arc volcanism, including (i) the models by Varne (1985), which was more specifically developed for the Banda arc sector but still bears some relevance to the Java rear-arc volcanism; (ii) the model of Edwards et al. (1994) targeting the volcanism at Mt. Muria as well as (iii) the model by Stolz et al. (1996), which, however, only refers to the origin of source components but does not put it into a broader geodynamic context.

Varne (1985) tentatively suggested partial melting of enriched, potentially old, subcontinental lithospheric mantle trapped in the subduction zone for the sources of arc volcanics that show affinities to ultrapotassic, orogenic lamproites. He developed his model for the Eastern sector of the SundaBanda arc (essentially to the east of Bali-Lombok), where some arc volcanism bears strong resemblance to Australian leucitites. Edwards et al. (1994) proposed a variation of this model for the Muria lavas, which were assumed to be produced by mixing of an I-MORB-type mantle with a metasomatic layer that these authors inferred to be derived from melts of deep recycled EM-II-type material that froze at the base of the lithospheric mantle. Melting of this hybrid mantle is proposed to occur by extension and decompression melting, potentially related to the extension occurring in the Bawean trough.

From the geochemical data and HFSE modelling presented here and elsewhere, a clear 'slab-melt' signature with residual garnet-rutile is evident in the rear-arc lavas. As such, in light of the models proposed by Varne (1985) and Edwards et al. (1994), the age of the purported 'slabmelt' mantle overprint needs to be addressed. If ancient lithospheric mantle would be involved as a source for the rear-arc lavas a significantly higher ${ }^{87} \mathrm{Sr} /{ }^{86} \mathrm{Sr}$ would be expected due to the time-integrated decay of $\mathrm{Rb}$ in a veined lithospheric mantle, where hydrous minerals like micas have high D's for Rb, as is, for example, reported for the Eastern Mediterranean (Prelević et al. 2005, 2008). Consequently, the Sunda rear-arc volcanism can likely be linked to the active Sunda subduction, which was indirectly suggested in the model by Stolz et al. (1996). These authors suggested that the superchondritic $\mathrm{Nb} / \mathrm{Ta}$ in the rear-arc lavas can be explained by partial melts derived from the subducting slab with residual rutile, hybridizing the depleted mantle wedge to form phlogopite-bearing harzburgite/lherzolite or orthopyroxenite/websterite. However, melting of the subducted plate is not a common process in a normal subduction zone environment, and is restricted to settings where very young or fragmented oceanic plates are involved (e.g., Kay 1978; Defant and Drummond 1990; Stern and Kilian 1996; Yogodzinski et al. 2001; König et al. 2007; König and Schuth 2011; Schuth et al. 2004, 2009). For the Sunda arc, subduction of very young (hot) lithosphere can be ruled out as the subducting oceanic plate is relatively old (45-80 Ma), and is subducting at a steep angle of $60-70^{\circ}$ (see Hall and Spakman 2015, and references therein). However, in the case of Central and East Java, a slab window or slab tear as an alternative mechanism for increasing the heat flow to trigger partial slab-melting is supported by geophysical evidence, reporting a seismic gap at $250-500 \mathrm{~km}$ depth (Widiyantoro and van der Hilst 1996; Koulakov et al. 2007; Hall 2002; Cottam et al. 2010; Widiyantoro et al. 2011; Hall and Spakman 2015). As noted by Cottam et al. (2010), and in a more recent review paper by Hall and Spakman (2015), the size and position of the slab window or slab tear requires that it was formed at $\sim 8 \mathrm{Ma}$, which rules out the current subduction of the Roo Rise as an underlying cause as previously suggested (e.g. Garwin 2002; Simandjuntak and Barber 1996; van der Werff et al. 1994). The slab window or slab tear is assumed to have developed in front of a buoyant plateau other than the Roo Rise while subduction along the other arc segments continued, thus augmenting and widening 
the developing slab tear. Moreover, thrusting in the upper crust of Java (Cross 2013; Lunt et al. 2009) is preceded by a paucity in arc volcanism in Eastern Java in the late Miocene ( $10 \mathrm{Ma})$ until the late Pliocene ( $3 \mathrm{Ma})$. The lack in arc volcanism coincides with the plateau uplift and the purported developing slab tear passing underneath the arc, thus effectively terminating the arc volcanism and triggering the melting of the slab-melt metasomatized deeper mantle domains by an increased heat flow permitted through the tear in the slab. This can explain both the hybrid (i.e. combined mafic slab-melt and sediment-melt metasomatized) and K-rich character of the rear-arc lavas and the short-lived volcanic activity in the rear-arc (see Hall and Spakman 2015, and references therein). The high-K nature in combination with the superchondritic $\mathrm{Nb} / \mathrm{Ta}$ and high HFSE concentrations of the Sunda rear-arc volcanism highlights the importance of subducted continental sediments as a metasomatizing agent carrying incompatible elements to the deeper parts of the mantle. For example, in other settings where partial slab melting occurs (e.g., the Solomon Islands, SW Pacific) the occurrence of slab-melts is demonstrated to be linked to virtually sediment-free, or rather volcanogenic sediments only, melting of subducted lithosphere (e.g., Schuth et al. 2009), resulting in picritic to andesitic-dacitic arc lavas of the low-K series (König et al. 2007; Schuth et al. 2004, 2009). Thus, the Sunda rear-arc lavas hitherto represent a somewhat unique occurrence of lavas with source components including slab-melt and sediment-melt source components.

\section{Conclusions}

The high-precision HFSE dataset presented here for lavas from the Indonesian Sunda frontal arc and rear-arc provides further insights into systematic along and across-arc variations of source and subduction components and the origin of high- $\mathrm{Nb} / \mathrm{Ta}$ lavas in subduction zones.

Using the geochemical dataset obtained here, we can confirm along-arc variations that correlate with distinct subduction components. The HFSE signatures along the frontal-arc together with source modelling confirm a control by subduction components on $\mathrm{Zr} / \mathrm{Nb}, \mathrm{Zr} / \mathrm{Hf}$, W/Th, whereas other HFSE ratios (e.g., $\mathrm{Nb} / \mathrm{Ta}$ ) reflect the Indian MORB mantle source of the frontal arc lavas.

While most HFSE ratios in the rear-arc lavas indicate an enriched mantle source (low $\mathrm{Zr} / \mathrm{Nb}$, high $\mathrm{Zr} / \mathrm{Hf}$, high HFSE concentrations), their most striking feature are the superchondritic $\mathrm{Nb} / \mathrm{Ta}$. They reach superchondritic values of up to 25 , which is somewhat lower compared to previous literature data (33; Stolz et al. 1996), but still remarkably high. As confirmed by our melting models the residual mineral phases in slab melts controlling the HFSE budget in the rear-arc lavas are rutile for $\mathrm{Nb}-\mathrm{Ta}$ and $\mathrm{cpx}$ for $\mathrm{Zr}-\mathrm{Hf}$. We propose a source of the slab melts in the eclogite stability field, involving a mafic protolith consisting of garnet(15\%)-cpx $(85 \%)$ and small amounts of rutile $(0.1 \%)$. This slab-derived component is complemented by various amounts of sediment components, as shown by diagnostic correlations of $\mathrm{Nb} / \mathrm{Ta}$ with some radiogenic isotope composition.

A tentative tectono-magmatic model for the rear-arc lavas includes melting of a mantle domain metasomatized by subduction-components that formed along a slab tear at $\sim 8 \mathrm{Ma}$. While the tectono-magmatic setting of the rear-arc lavas is somewhat unique and its activity short-lived, it nevertheless shows that there are sub-arc domains consisting of strongly metasomatized regions that are highly enriched in HFSE and, in the Sunda case, particularly enriched in $\mathrm{Nb}$ and $\mathrm{W}$. Further investigation might show how relevant these reservoirs are for the global HFSE budget with respect to a high- $\mathrm{Nb} / \mathrm{Ta}$ end member.

Supplementary Information The online version contains supplementary material available at https://doi.org/10.1007/s00410-021-01871-9.

Acknowledgements $\mathrm{M}$. Kirchenbaur acknowledges funding by the German Research Foundation (DFG grant KI 1802/1-1) and C. Münker by DFG grant $1406 / 9$. Parts of the sampling campaign were funded by a DAAD academic exchange program. S. König acknowledges support from ERC STG project O2RIGIN (636808). We would like to thank F. Wombacher, and A. Katzemich for lab support at the University of Cologne, S. Viehmann and H. Poppe for help during the sampling campaign, and J.E. Hoffmann for discussions and mass spectrometry assistance in Bonn. The help of U. Westernströer (University of Kiel) with ICP-MS analyses is greatly appreciated. The reviews by Bill Leeman and Marcel Regelous are highly appreciated and significantly improved the manuscript. We also acknowledge the comments of two anonymous reviewers on an earlier version of the manuscript.

Funding Open Access funding enabled and organized by Projekt DEAL.

Open Access This article is licensed under a Creative Commons Attribution 4.0 International License, which permits use, sharing, adaptation, distribution and reproduction in any medium or format, as long as you give appropriate credit to the original author(s) and the source, provide a link to the Creative Commons licence, and indicate if changes were made. The images or other third party material in this article are included in the article's Creative Commons licence, unless indicated otherwise in a credit line to the material. If material is not included in the article's Creative Commons licence and your intended use is not permitted by statutory regulation or exceeds the permitted use, you will need to obtain permission directly from the copyright holder. To view a copy of this licence, visit http://creativecommons.org/licenses/by/4.0/.

\section{References}

Bali E, Keppler H, Audetat A (2012) The mobility of W and Mo in subduction zone fluids and the Mo-W-Th-U systematics of island arc magmas. Earth Planet Sci Lett 351-352:195-207 
Barth MG, McDonough WF, Rudnick RL (2000) Tracking the budget of $\mathrm{Nb}$ and $\mathrm{Ta}$ in the continental crust. Chem Geol 165:197-213

Bebout GE (2007) Metamorphic chemical geodynamics of subduction zones. Earth Planet Sci Lett 260:373-393

Bebout GE, Barton MD (2002) Tectonic and metasomatic mixing in a high-T, subduction-zone mélange-insights into the geochemical evolution of the slab-mantle interface. Chem Geol 187:79-106

Ben-Avraham Z, Emery KO (1973) Structural framework of Sunda Shelf. Am Assoc Petrol Geol Bull 57:2323-2366

Brenan JM, Shaw HF, Phinney DL, Ryerson FJ (1994) Rutile-aqueous fluid partitioning of $\mathrm{Nb}, \mathrm{Ta}, \mathrm{Hf}, \mathrm{Zr}, \mathrm{U}$ and $\mathrm{Th}$ : implications for high field strength element depletions in island-arc basalts. Earth Planet Sci Lett 128:327-339

Büchl A, Münker C, Mezger K, Hofmann AW (2002) High-precision $\mathrm{Nb} / \mathrm{Ta}$ and $\mathrm{Zr} / \mathrm{Hf}$ ratios in global MORB. Geochim Et Cosmochim Acta 66(15A):A108-A108

Carpentier M, Chauvel C, Maury RC, Mattielli N (2009) The "zircon effect" as recorded by the chemical and Hf isotopic compositions of Lesser Antilles forearc sediments. Earth Planet Sci Lett 287:86-99

Cartier C, Hammouda T, Boyet M, Bouhifd MA, Devidal JL (2014) Redox control of the fractionation of niobium and tantalum during planetary accretion and core formation. Nat Geosci 7:573-576

Castro A, Gerya T, García-Casco A, Fernández C, Díaz-Alvarado J, Moreno-Ventas I, Löw I (2010) Melting relations of MORBsediment mélanges in underplated mantle wedge plumes; Implications for the origin of Cordilleran-type batholiths. J Petrol 51:1267-1295

Chadwick JP, Troll VR, Ginibre C, Morgan D, Gertisser R, Waight TE, Davidson JP (2007) Carbonate assimilation at Merapi Volcano, Java, Indonesia: Insights from crystal isotope stratigraphy. J Petrol 48:1793-1812

Chen W, Xiong X, Wang J, Xue S, Li L, Liu X, Ding X, Song M (2018) $\mathrm{TiO}_{2}$ solubility and $\mathrm{Nb}$ and Ta partitioning in rutile-silica-rich supercritical fluid systems: implications for subduction zone processes. J Geophys Res Solid Earth 123:4765-4782

Chotin P, Rasplus L, Rampnoux JP, Suminta NH (1984) Major strike slip fault zone and associated sedimentation in the central part of Java island (Indonesia). Bull Soc Geol France 6:1259-1268 (in French)

Cottam M, Hall R, Cross L, Clements B, Spakman W (2010) Neogene subduction beneath Java, Indonesia: Slab tearing and changes in magmatism. Geophys Res Abstr 12:12437

Cross L (2013) Neogene evolution of Java. PhD thesis, University of London

Crusius J, Calvert S, Pedersen T, Sage D (1996) Rhenium and molybdenum enrichments in sediments as indicators of oxic, suboxic and sulfidic conditions of deposition. Earth Planet Sci Lett 145:65-78

Cruz-Uribe AM, Marschall HR, Gaetani GA, Le Roux V (2018) Generation of alkaline magmas in subduction zones by partial melting of mélange diapirs-an experimental study. Geology 46:343-346

David K, Schiano P, Allègre CJ (2000) Assessment of the $\mathrm{Zr} / \mathrm{Hf}$ fractionation in oceanic basalts and continental materials during petrogenetic processes. Earth Planet Sci Lett 178:285-301

Deegan FM, Troll VR, Freda C, Misiti V, Chadwick JP, McLeod CL, Davidson JP (2010) Magma-carbonate interaction processes and associated $\mathrm{CO}_{2}$ release at Merapi Volcano, Indonesia: insights from experimental petrology. J Petrol 51:1027-1051

Defant MJ, Drummond MS (1990) Derivation of some modern island arc magmas by melting of young subducted lithosphere. Nature 347:662-665

Edwards CMH, Menzies MA, Thirlwall MF, Morris JD, Leeman WP, Harmon RS (1994) The transition to potassic alkaline volcanism in island arcs: the Ringgit-Beser complex, east Java Indonesia. J Petrol 35:1557-1595

Elliott T, Plank T, Zindler A, White W, Bourdon B (1997) Element transport from slab to volcanic front at the Mariana arc. J Geophys Res 102:14991-15019

Foley SF, Venturelli G, Green DH, Toscani L (1987) The ultrapotassic rocks: characteristics, classification, and constraints for petrogenetic models. Earth Sci Rev 24:81-134

Foley SF, Barth MG, Jenner GA (2000) Rutile/melt partition coefficients for trace elements and an assessment of the influence of rutile on the trace element characteristics of subduction zone magmas. Geochim Cosmochim Acta 64:933-938

Foley S, Tiepolo M, Vannucci R (2002) Growth of early continental crust controlled by melting of amphibolite in subduction zones. Nature 417:837-840

Gale A, Dalton CA, Langmuir CH, Su Y, Schilling J-G (2013) The mean composition of ocean ridge basalts. Geochem Geophys Geosyst 14:489-518

Garbe-Schönberg C-D (1993) Simultaneous determination of thirtyseven trace elements in twenty-eight international rock standards by ICP-MS. Geostand Geoanal Res 17:81-97

Garwin S (2002) The geologic setting of intrusion-related hydrothermal systems near the Batu Hijau porphyry copper-gold deposit, Sumbawa, Indonesia. Soc Econ Geol Spec Publ 9(9):333-366

Gertisser R, Keller J (2003) Trace element and Sr, Nd, Pb and O isotope variations in medium-K and high-K volcanic rocks from Merapi Volcano, Central Java, Indonesia: evidence for the Involvement of Subducted Sediments in Sunda Arc Magma Genesis. J Petrol 44:457-489

Green TH (1995) Significance of $\mathrm{Nb} / \mathrm{Ta}$ as an indicator of geochemical processes in the crust-mantle system. Chem Geol 120:347-359

Hart SR (1984) A large-scale isotope anomaly in the southern-hemisphere mantle. Nature 309:753-757

Hall R (2002) Cenozoic geological and plate tectonic evolution of SE Asia and the SW Pacific. J Asian Earth Sci 20:353-431

Hall R, Spakman W (2015) Mantle structure and tectonic history of SE Asia. Tectonophysics 658:14-45

Hamilton W (1973) Tectonics of the Indonesian Region. Bull Geol Soc Malays 6:3-10

Hamilton W (1979) Tectonics of the Indonesian region. Geol Surv Prof Paper 1078, US Govt Printing Office

Handley HK (2006) Geochemical and Sr-Nd-Hf-O isotopic constraints on volcanic petrogenesis at the Sunda arc, Indonesia. $\mathrm{PhD}$ thesis, Durham University

Handley HK, Macpherson CG, Davidson JP, Berlo K, Lowry D (2007) Constraining fluid and sediment contributions to subductionrelated magmatism in Indonesia: Ijen Volcanic Complex. J Petrol 48:1155-1183

Handley HK, Turner S, Macpherson CG, Gertisser R, Davidson JP (2011) Hf-Nd isotope and trace element constraints on subduction inputs at island arcs: limitations of $\mathrm{Hf}$ anomalies as sediment input indicators. Earth Planet Sci Lett 304:212-223

Handley HK, Blichert-Toft J, Gertisser R, Macpherson CG, Turner SP, Zaennudin A, Abdurrachman M (2014) Insights from $\mathrm{Pb}$ and $\mathrm{O}$ isotopes into along-arc variations in subduction inputs and crustal assimilation for volcanic rocks in Java, Sunda arc Indonesia. Geochim Cosmochim Acta 139:205-226

Hauri EH, Wagner TP, Grove TL (1994) Experimental and natural partitioning of Th, $\mathrm{U}, \mathrm{Pb}$ and other trace elements between garnet, clinopyroxene and basaltic melts. Chem Geol 117:149-166

Hawkesworth CJ, Gallagher K, Hergt JM, McDermott F (1993) Trace element fractionation processes in the generation of island arc basalts. Phil Trans Phys Sci Eng 342:179-191

Hermann J, Rubatto D (2009) Accessory phase control on the trace element signature of sediment melts in subduction zones. Chem Geol 265:512-526 
Hofmann AW (2014) Sampling mantle heterogeneity through oceanic basalts: Isotopes and trace elements 2.03. In: Holland $\mathrm{H}$, Turekian KK (Hrsg.): Treatise on geochemistry. Band 2: the mantle and core. Elsevier-Pergamon, Oxford. ISBN 0-08044848-8, S. pp 67-101

Hoffmann-Rothe A, Ritter O, Haak V (2001) Magnetotelluric and geomagnetic modelling reveals zones of very high electrical conductivity in the upper crust of Central Java. Phys Earth Planet Inter 124:131-151

Hoffmann JE, Münker C, Næraa T, Rosing MT, Herwartz D, GarbeSchönberg D, Svahnberg H (2011) Mechanisms of Archean crust formation inferred from high-precision HFSE systematics in TTGs. Geochim Cosmochim Acta 75:4157-4178

Iddings JP, Morley EW (1915) Contributions to the petrography of Java and celebes. J Geol 23:231-245

Jenner FE, O'Neill HSC (2012) Analysis of 60 elements in 616 ocean floor basaltic glasses. Geochem Geophys Geosystems 13:1-11

Katili JA (1975) Volcanism and plate tectonics in the Indonesian island arcs. Tectonophysics 26:165-188

Kay RW (1978) Aleutian magnesian andesite: Melts from subducted Pacific Ocean crust. J Volcanol Geotherm Res 4:497-522

Kessel R, Schmidt MW, Ulmer P, Pettke T (2005) Trace element signature of subduction-zone fluids, melts and supercritical liquids at $120-180 \mathrm{~km}$ depth. Nature 437:724-727

Kirchenbaur M, Münker C (2015) The behaviour of the extended HFSE group (Nb, Ta, Zr, Hf, W, Mo) during the petrogenesis of mafic K-rich lavas: the Eastern Mediterranean case. Geochim Cosmochim Acta 165:178-199

Klein M, Stosch H-H, Seck HA (1997) Partitioning of high fieldstrength and rare-earth-elements between amphibole and quartzdioritic melts: an experimental study. Chem Geol 138:257-271

Klemme S, Blundy JD, Wood BJ (2002) Experimental constraints on major and trace element partitioning during partial melting of eclogite. Geochim Cosmochim Acta 66:3109-3123

Klemme S, Prowatke S, Hametner K, Günther D (2005) Partitioning of trace elements between rutile and silicate melts: implications for subduction zones. Geochim Cosmochim Acta 69:2361-2371

Klemme S, Günther D, Hametner K, Prowatke S, Zack T (2006) The partitioning of trace elements between ilmenite, ulvospinel, armalcolite and silicate melts with implications for the early differentiation of the moon. Chem Geol 234:251-263

König S, Schuth S (2011) Deep melting of old subducted oceanic crust recorded by superchondritic $\mathrm{Nb} / \mathrm{Ta}$ in modern island arc lavas. Earth Planet Sci Lett 301:265-274

König S, Schuth S, Münker C, Qopoto C (2007) The role of slab melting in the petrogenesis of high- $\mathrm{Mg}$ andesites: Evidence from Simbo Volcano Solomon Islands. Contrib Mineral Petrol 153:85-103

König S, Münker C, Schuth S, Garbe-Schönberg D (2008) Mobility of tungsten in subduction zones. Earth Planet Sci Lett 274:82-92

König S, Münker C, Schuth S, Luguet A, Hoffmann JE, Kuduon J (2010) Boninites as windows into trace element mobility in subduction zones. Geochim Cosmochim Acta 74:684-704

König S, Münker C, Hohl S, Paulick H, Barth AR, Lagos M, Pfänder J, Büchl A (2011) The Earth's tungsten budget during mantle melting and crust formation. Geochim Cosmochim Acta 75:2119-2136

König S, Wille M, Voegelin A, Schoenberg R (2016) Molybdenum isotope systematics in subduction zones. Earth Planet Sci Lett 447:95-102

Kopp H, Flueh ER, Petersen CJ, Weinrebe W, Wittwer A, Scientists M (2006) The Java margin revisited: evidence for subduction erosion off Java. Earth Planet Sci Lett 242:130-142

Korkisch J, Hazan I (1965) Anion exchange separations in hydrobromic acid-organic solvent media. Anal Chem 37:707-710
Koulakov I, Bohm M, Asch G, Lühr BG, Manzanares A, Brotopuspito KS, Fauzi P, Purbawinata MA, Puspito NT, Ratdomopurbo A, Kopp H, Rabbel W, Shevkunova E (2007) P and S velocity structure of the crust and the upper mantle beneath central Java from local tomography inversion. J Geophys Res Solid Earth 112:1-19

Kurzweil F, Münker C, Grupp M, Braukmüller N, Fechtner L, Christian M, Hohl SV, Schoenberg R (2019) The stable tungsten isotope composition of modern igneous reservoirs. Geochim Cosmochim Acta 251:176-191

Leitzke FP, Fonseca ROC, Michely LT, Sprung P, Münker C, Heuser A, Blanchard H (2016) The effect of titanium on the partitioning behavior of high-field strength elements between silicates, oxides and lunar basaltic melts with applications to the origin of mare basalts. Chem Geol 440:219-238. https://doi.org/10.1016/j. chemgeo.2016.07.011

Leterrier J, Yuwono YS, Soeria-Atmadja R, Maury RC (1990) Potassic volcanism in Central Java and South Sulawesi Indonesia. J Southeast Asian Earth Sci 4:171-187

Lunt P, Burgon G, Baky A (2009) The Pemali Formation of Central Java and equivalents: indicators of sedimentation on an active plate margin. J Asian Earth Sci 34:100-113

Macpherson CG, Dreher ST, Thirlwall MF (2006) Adakites without slab melting: High pressure differentiation of island arc magma, Mindanao, the Philippines. Earth Planet Sci Lett 243:581-593

Marschall HR, Schumacher JC (2012) Arc magmas sourced from mélange diapirs in subduction zones. Nat Geosci 5:862-867

McDade P, Blundy JD, Wood BJ (2003) Trace element partitioning on the Tinaquillo solidus at $1.5 \mathrm{GPa}$. Phys Earth Planet Inter 139:129-147

Mibe K, Kanzaki M, Kawamoto T, Matsukage KN, Fei Y, Ono S (2007) Second critical endpoint in the peridotite- $\mathrm{H}_{2} \mathrm{O}$ system. J Geophys Res: Solid Earth 112:1-8

Moore GF, Curray JR, Moore DG, Karig DE (1980) Variations in geologic structure along the Sunda fore arc, northeastern Indian Ocean. In: Hayes DE (ed) The tectonic and geologic evolution of southeast Asian Seas and Islands. Am Geophys Union, Washington, pp 145-160

Münker C, Weyer S, Scherer E, Mezger K (2001) Separation of high field strength elements ( $\mathrm{Nb}, \mathrm{Ta}, \mathrm{Zr}, \mathrm{Hf})$ and Lu from rock samples for MC-ICPMS measurements. Geochem Geophys Geosyst. https://doi.org/10.1029/2001GC000183

Münker C, Pfänder JA, Weyer S, Büchl A, Kleine T, Mezger K (2003) Evolution of planetary cores and the Earth-Moon system from $\mathrm{Nb} / \mathrm{Ta}$ systematics. Science 301:84-87

Münker C, Wörner G, Yogodzinski G, Churikova T (2004) Behaviour of high field strength elements in subduction zones: constraints from Kamchatka-Aleutian arc lavas. Earth Planet Sci Lett 224:275-293

Münker C, Fonseca ROC, Schulz T (2017) Silicate Earth's missing niobium may have been sequestered into asteroidal cores. Nat Geosci 10:822-826

Nebel O, Vroon PZ, Wiggers de Vries DF, Jenner FE, Mavrogenes JA (2010) Tungsten isotopes as tracers of core-mantle interactions: The influence of subducted sediments. Geochim Cosmochim Acta 74:751-762

Newsom HE, Sims KWW, Noll PD, Jaeger WL, Maehr SA, Beserra TB (1996) The depletion of tungsten in the bulk silicate earth: constraints on core formation. Geochim Cosmochim Acta 60:1155-1169

Nicholls IA, Whitford DJ (1983) Potassium-rich volcanic rocks of the Muriah complex, Java, Indonesia: Products of multiple magma sources? J Volcanol Geotherm Res 18:337-359

Nicolas A (1986) A melt extraction model based on structural studies in mantle peridotites. J Petrol 27:99-1022

Nielsen SG, Marschall HR (2017) Geochemical evidence for mélange melting in global arcs. Sci Adv 3:1-7 
Nobre SI, G., Weis D., Scoates J. S. and Barling J. (2013) The ninetyeast ridge and its relation to the Kerguelen, Amsterdam and St. Paul hotspots in the Indian Ocean. J Petrol 54:1177-1210

Nutman AP, McGregor VR, Friend CRL, Bennett VC, Kinny PD (1996) The Itsaq Gneiss Complex of southern-west Greenland: the world's most extensive record of early crustal evolution (3900-3600 Ma). Precamb Res 78:1-39

Palme H, Rammensee W (1981) Tungsten and some other siderophile elements in meteoritic and terrestrial basalts. Lunar Planet Sci XII:796-798

Palme H, O'Neill H, St. C (2014) Cosmochemical constraints on mantle composition. In: Carlson RW, Holland HD, Turekian KK (eds) Treatise on Geochemistry, vol 2. pp. 568. ISBN 0-08043751-6. Elsevier, 2014, p 1-38

Pearce JA, Peate DW (1995) Tectonic implications of the composition of volcanic arc magmas. Annu Rev Earth Planet Sci 23:251-285

Pearce JA, Kempton PD, Nowell GM, Noble SR (1999) Hf-Nd element and isotope perspective on the nature and provenance of mantle and subduction components in Western Pacific arc-basin systems. J Petrol 40:1579-1611

Peccerillo A, Taylor SR (1976) Geochemistry of Eocene calc-alkaline volcanic rocks from the Katamonu area, northern Turkey. Contrib to Mineral Petrol 81:63-81

Pfänder JA, Jung S, Münker C, Stracke A, Mezger K (2012) A possible high $\mathrm{Nb} / \mathrm{Ta}$ reservoir in the continental lithospheric mantle and consequences on the global $\mathrm{Nb}$ budget-evidence from continental basalts from Central Germany. Geochim Cosmochim Acta 77:232-251

Pin C, Zalduegui JFS (1997) Sequential separation of light rare-earth elements, thorium and uranium by miniaturized extraction chromatography: application to isotopic analyses of silicate rocks. Anal Chim Acta 339:79-89

Plank T, Langmuir CH (1998) The chemical composition of subducting sediment and its consequences for the crust and mantle. Chem Geol 145:325-394

Prelević D, Foley SF, Romer RL, Cvetković V, Downes H (2005) Tertiary ultrapotassic volcanism in Serbia: constraints on petrogenesis and mantle source characteristics. J Petrol 46:1443-1487

Prelević D, Foley SF, Romer R, Conticelli S (2008) Mediterranean tertiary lamproites derived from multiple source components in postcollisional geodynamics. Geochim Cosmochim Acta 72:2125-2156

Putnis A, Putnis CV (2007) The mechanism of reequilibration of solids in the presence of a fluid phase. J Solid State Chem 180:1783-1786

Rempel KU, Williams-Jones AE, Migdisov AA (2009) The partitioning of molybdenum(VI) between aqueous liquid and vapour at temperatures up to $370{ }^{\circ} \mathrm{C}$. Geochim Cosmochim Acta 73:3381-3392

Ringwood AE (1976) Phase transformations in descending plates and implications for mantle dynamics. Tectonophysics 32:129-143

Rudnick RL (2000) Rutile-bearing refractory eclogites: missing link between continents and depleted mantle. Science 287:278-281

Salters VJM, Stracke A (2004) Composition of the depleted mantle. Geochem Geophys Geosyst 5

Schuth S, Rohrbach A, Münker C, Ballhaus C, Garbe-Schönberg D, Qopoto C (2004) Geochemical constraints on the petrogenesis of arc picrites and basalts, New Georgia Group Solomon Islands. Contrib Mineral Petrol 148:288-304

Schuth S, Münker C, König S, Qopoto C, Basi S, Garbe-Schönberg D, Ballhaus C (2009) Petrogenesis of lavas along the Solomon Island Arc, SW Pacific: coupling of compositional variations and subduction zone geometry. J Petrol 50:781-811

Schuth S, König S, Münker C (2011) Subduction zone dynamics in the SW Pacific plate boundary region constrained from high-precision $\mathrm{Pb}$ isotope data. Earth Planet Sci Lett 311:328-338
Shaw DM (1970) Trace element fractionation during anatexis. Geochim Cosmochim Acta 34:237-243

Simandjuntak TO, Barber AJ (1996) Contrasting tectonic styles in the Neogene orogenic belts of Indonesia. In: Hall R, Blundell DJ (eds) Tectonic Evolution of SE Asia. Geological Society of London Special Publication 106, London, pp 185-201

Smyth HR, Hamilton PJ, Hall R, Kinny PD (2007) The deep crust beneath island arcs: Inherited zircons reveal a Gondwana continental fragment beneath East Java Indonesia. Earth Planet Sci Lett 258:269-282

Sun SS, McDonough WF (1989) Chemical and isotopic systematics of oceanic basalts: implications for mantle composition and processes. In: Saunders AD, Norry MJ (eds) Magmatism in the Ocean Basins, Geological Society, London, Special Publications, vol. 42, pp 313-345

Stalder R, Foley SF, Drey GP, Horn I (1998) Mineral-aqueous fluid partitioning of trace elements at $900-1200{ }^{\circ} \mathrm{C}$ and 3.0-5.7 GPa: new experimental data for garnet, clinopyroxene, and rutile, and implications for mantle metasomatism. Geochim Cosmochim Acta 62:1781-1801

Stern CR, Kilian R (1996) Role of the subducted slab, mantle wedge and continental crust in the generation of adakites from the Andean Austral Volcanic Zone. Contrib Mineral Petrol 123:263-281

Stolz AJ, Jochum KP, Spettel B, Hofmann AW (1996) Fluid- and meltrelated enrichment in the subarc mantle: evidence from $\mathrm{Nb} / \mathrm{Ta}$ variations in island-arc basalts. Geology 24:587-590

Tanis EA, Simon A, Tschauner O, Chow P, Xiao Y, Burnley P, Cline CJ II, Hanchar JM, Pettke T, Shen G, Zhao Y (2015) The mobility of $\mathrm{Nb}$ in rutile-saturated $\mathrm{NaCl}-$ and $\mathrm{NaF}$ - bearing aqueous fluids from 1-6.5 GPa and 300-800 ${ }^{\circ} \mathrm{C}$. Am Mineral 100:1600-1609

Tatsumi Y (1989) Migration of a fluid phase and genesis of basalt magmas in subduction zones. J Geophys Res 94:4697-4707

Troll VR, Deegan FM, Jolis EM, Harris C, Chadwick JP, Gertisser R, Schwarzkopf LM, Borisova AY, Bindeman IN, Sumarti S, Preece K (2013) Magmatic differentiation processes at Merapi Volcano: inclusion petrology and oxygen isotopes. J Volcanol Geotherm Res 261:38-49

Turner S, Foden J (2001) U, Th and Ra disequilibria, Sr, Nd and Pb isotope and trace element variations in Sunda arc lavas: Predominance of a subducted sediment component. Contrib Mineral Petrol 142:43-57

Turner SP, Zaennudin A, Handley HK, Macpherson CG, Blichert-Toft J, Abdurrachman M, Gertisser R (2014) Insights from $\mathrm{Pb}$ and $\mathrm{O}$ isotopes into along-arc variations in subduction inputs and crustal assimilation for volcanic rocks in Java, Sunda arc Indonesia. Geochim Cosmochim Acta 139:205-226

van Bemmelen RW (1970) The geology of Indonesia, 2nd edn. Martinus Nijhoff, The Hague

van Bergen MJ, Vroon PZ, Hoogewerff JA (1993) Geochemical and tectonic relationships in the east Indonesian arc-continent collision region: implications for the subduction of the Australian passive margin. Tectonophysics 223:97-116

van der Werff W, Kusnida D, Prasetyo H, van Weering TCE (1994) Origin of the Sumba forearc basement. Mar Pet Geol 11:363-374

Van Westrenen W, Blundy J, Wood B (1999) Crystal-chemical controls on trace element partitioning between garnet and anhydrous silicate melt. Am Mineral 84:838-847

Varekamp JC, van Bergen JM, Vroon PZ, Poorter RPE, Wirakusumah AD, Erfan RD, Suharyono K, Sriwana T, Van HJE, van_Weering TC, Fortuin AR, Baretta BJG, Stel JH (1989) Volcanism and tectonics in the eastern Sunda Arc, Indonesia. In: Geology and geophysics of the Banda Arc and adjacent areas; I: proceedings of the Snellius II symposium. Netherlands J Sea Res 24, 303-312

Varne R (1985) Ancient subcontinental mantle: a source for K-rich orogenic volcanics. Geology 13:405-408 
Vigouroux N, Wallace PJ, Williams-Jones G, Kelley K, Kent AJR, Williams-Jones AE (2012) The sources of volatile and fluid-mobile elements in the Sunda arc: a melt inclusion study from Kawah Ijen and Tambora volcanoes, Indonesia. Geochem Geophys Geosyst $13: 1-22$

Vroon PZ, van Bergen MJ, Klaver GJ, White WM (1995) Strontium, neodymium, and lead isotopic and trace-element signatures of the East indonesian sediments: provenance and implications

Vukadinovic D (1995) High-field-strength elements in Javanese arc basalts and chemical layering in the mantle wedge. Mineral Petrol 55:293-308

Wade J, Wood BJ (2001) The Earth's "missing" niobium may be in the core. Nature 409:75-78

Wade J, Wood BJ, Tuff J (2012) Metal-silicate partitioning of Mo and W at high pressures and temperatures: evidence for late accretion of sulphur to the Earth. Geochim Cosmochim Acta 85:58-74

Weyer S, Münker C, Rehkämper M, Mezger K (2002) Determination of ultra-low $\mathrm{Nb}, \mathrm{Ta}, \mathrm{Zr}$ and $\mathrm{Hf}$ concentrations and the chondritic $\mathrm{Zr} / \mathrm{Hf}$ and $\mathrm{Nb} / \mathrm{Ta}$ ratios by isotope dilution analyses with multiple collector ICP-MS. Chem Geol 187:295-313

Weyer S, Münker C, Mezger K (2003) Nb/Ta, Zr/Hf and REE in the depleted mantle: implications for the differentiation history of the crust-mantle system. Earth Planet Sci Lett 205:309-324

Wheller GE, Varne R, Foden JD, Abbott MJ (1987) Geochemistry of quaternary volcanism in the Sunda-Banda arc, Indonesia, and three-component genesis of island-arc basaltic magmas. J Volcanol Geotherm Res 32:137-160

Whitford DJ (1975) Strontium isotopic studies of the volcanic rocks of the Sunda arc, Indonesia, and their petrogenetic implications. Geochim Cosmochim Acta 39:1287-1302

Widiyantoro S, van der Hilst R (1996) Structure and evolution of lithospheric slab beneath the Sunda arc, Indonesia. Science 271:1566-1570
Widiyantoro S, Pesicek JD, Thurber CH (2011) Subducting slab structure below the eastern Sunda arc inferred from non-linear seismic tomographic imaging. Geol Soc Spec Publ 355:139-155

Wijbrans CH, Klemme S, Berndt J, Vollmer C (2015) Experimental determination of trace element partition coefficients between spinel and silicate melt: the influence of chemical composition and oxygen fugacity. Contrib Mineral Petrol 169:45

Woodhead JD, Hergt JM, Davidson JP, Eggins SM (2001) Hafnium isotope evidence for "conservative" element mobility during subduction zone processes. Earth Planet Sci Lett 192:331-346

Workman RK, Hart SR (2005) Major and trace element composition of the depleted MORB mantle (DMM). Earth Planet Sci Lett 231:53-72

Xiong XL, Adam J, Green TH (2005) Rutile stability and rutile/melt HFSE partitioning during partial melting of hydrous basalt: Implications for TTG genesis. Chem Geol 218:339-359

Yaxley GM, Green DH (1998) Reactions between eclogite and peridotite: Mantle refertilisation by subduction of oceanic crust. Schweiz Mineral Petrogr Mitt 78:243-255

Yogodzinski GM, Lees JM, Churikova TG, Dorendorf F, Wörner G, Volynets ON (2001) Geochemical evidence for the melting of subducting oceanic lithosphere at plate edges. Nature 409:500-504

Zack T, Kronz A, Foley SF, Rivers T (2002) Trace element abundances in rutiles from eclogites and associated garnet mica schists. Chem Geol 184:97-122

Zou H (2007) Quantitative geochemistry. Imperial College Press, p 304

Publisher's Note Springer Nature remains neutral with regard to jurisdictional claims in published maps and institutional affiliations. 